\title{
Long-term time-series study of salp population dynamics in the Sargasso Sea
}

\author{
Joshua P. Stone ${ }^{1, *}$, Deborah K. Steinberg ${ }^{1}$ \\ ${ }^{1}$ Department of Biological Sciences, Virginia Institute of Marine Science, College of William \& Mary, PO Box 1346, \\ Gloucester Point, VA 23062, USA
}

\begin{abstract}
Salps are bloom-forming, pelagic tunicates with high grazing rates on phytoplankton, with the potential to greatly increase vertical particle flux through rapidly sinking fecal pellets. However, the frequency and causes of salp blooms are not well known. We quantified salps from day and night zooplankton net tows in the epipelagic zone of the North Atlantic subtropical gyre as part of the Bermuda Atlantic Time-series Study (BATS). Salp species and size were quantified in biweekly to monthly tows from April 1994 to November 2011. Twenty-one species of salps occurred at the BATS site over this time period, and the most common bloom-forming salps were Thalia democratica, Salpa fusiformis, Weelia (Salpa) cylindrica, Cyclosalpa polae, and Iasis zonaria. Five species of salps exhibited diel vertical migration, and salp abundances varied seasonally, with $T$. democratica, $S$. fusiformis, and $C$. polae blooms coincident with the spring phytoplankton bloom, and $W$. cylindrica blooms occurring more often in late summer. For T. democratica, mean annual biomass increased slightly over the time series and was elevated every 3 yr, and biomass increased in the presence of cyclonic mesoscale eddies. Decadal climate oscillations and biogeochemical conditions influenced multi-year trends in salp abundance and biomass. Both total salp and T. democratica abundance were positively correlated with primary production, total salp biomass was positively correlated with the North Pacific Gyre Oscillation, and T. democratica biomass was negatively correlated with the Pacific Decadal Oscillation. These salp bloom dynamics have important implications for planktonic food web interactions and biogeochemical cycling.
\end{abstract}

KEY WORDS: Salps · Thaliacea $\cdot$ Jellyfish blooms $\cdot$ Gelatinous zooplankton · Mesoscale eddies Thalia democratica $\cdot$ Sargasso Sea $\cdot$ Atlantic Ocean

Resale or republication not permitted without written consent of the publisher

\section{INTRODUCTION}

Salps are gelatinous, planktonic tunicates with a life history alternating between sexual and asexual stages, enabling them to rapidly replicate, forming high-density blooms when conditions are favorable (Godeaux et al. 1998). Salps are known to form large blooms in many regions of the world's oceans, including the Sargasso Sea (Madin et al. 1996, 2001, Roman et al. 2002), Mediterranean Sea (Ménard et al. 1994), Southern Ocean (Atkinson et al. 2004, Loeb \& Santora 2012), western Tasman Sea (Everett et al. 2011), southwestern Atlantic (Daponte et al. 2011), and Hauraki Gulf (Zeldis et al. 1995). Salps can feed efficiently on small phytoplankton and bacteria (Bone et al. 2003), have some of the highest clearance rates of any zooplankton - up to several liters $\mathrm{h}^{-1} \mathrm{salp}^{-1}$ (Harbison \& McAlister 1979, Madin \& Purcell 1992, Madin \& Kremer 1995), and can consume over $100 \%$ of the daily primary production (PP) (Hereu et al. 2006). These high clearance rates contribute to production by salps of large, fast-sinking fecal pellets (Caron et al. 1989, Sutherland et al. 2010b), with sinking rates ranging from 42 to $2700 \mathrm{~m} \mathrm{~d}^{-1}$ (Andersen 1998, Yoon et al. 2001, Phillips et al. 2009). Because of their high fecal pellet production rates, salp blooms have a significant effect on particle export (Madin 1982, Caron et al. 1989). This, coupled with sinking of dead car- 
casses (Lebrato \& Jones 2009, Henschke et al. 2013, Lebrato et al. 2013), represents a fast and efficient pathway for organic matter in the surface waters to move to depth. During a salp bloom, salps can thus be major contributors to the total carbon flux from the surface to the deep sea, as demonstrated in the Mediterranean Sea (Yoon et al. 1996, Fernex et al. 1996), Sargasso Sea (Conte et al. 2001), Southern Ocean (Phillips et al. 2009), and Tasman Sea (Henschke et al. 2013).

Salp populations are sensitive to interannual or longer-term changes in the environment (Ménard et al. 1994, Licandro et al. 2006). A long-term decrease in pelagic tunicates, particularly salps, in the California Current is attributed to a long-term increase in water column density stratification, which has weakened the eddy kinetics of the region as well as the southward flow of water and the seeding populations of salps within it (Lavaniegos \& Ohman 2007). Salp populations in some regions of the Southern Ocean have been increasing in abundance and expanding their range (Atkinson et al. 2004) as a result of longterm warming and decreases in sea ice (Vaughan et al. 2003, Stammerjohn et al. 2012). Variability in the Southern Ocean Antarctic Circumpolar Current Front causes fluctuations in salp abundance off the western Antarctic Peninsula (Loeb et al. 2010). Ménard et al. (1994) and Sutherland et al. (2010a) found salp abundance in the Mediterranean Sea declined in response to increases in temperature and stratification of the water column, which decreased mixing of nutrients to the surface and PP. Likewise, salp, doliolid, and pyrosome abundance in the South China Sea increased with an increase in chlorophyll a (chl a) concentration caused by coastal upwelling and injection of nutrients into surface waters by coldcore eddies in the summer (Li et al. 2011). While previous studies help us to understand salp population dynamics in coastal upwelling and continental shelf regions, very little is known about how salps respond to environmental changes in the open ocean.

The Sargasso Sea is an oligotrophic, open-ocean region of the western North Atlantic subtropical gyre, with patterns in the biogeochemistry of the region influenced by physical forcing with ties to decadal-scale climate oscillations (Saba et al. 2010, Álvarez-García et al. 2011, Wu et al. 2011). Longterm changes in regional biogeochemistry of the Sargasso Sea have been documented, including: an increase in net primary productivity correlated with the North Atlantic Oscillation (NAO) (Saba et al. 2010), increases in both shallow-water particulate organic carbon export and mesopelagic zone particle attenuation in the winter-spring period (Lomas et al.
2010), and an increase in epipelagic mesozooplankton biomass (Steinberg et al. 2012). Mesoscale eddies are an important physical feature in the Sargasso Sea also affecting ecosystem structure and biogeochemical cycling. Cyclonic (cold-core) eddies are an important periodic source of nutrient injection into the euphotic zone stimulating new PP (McGillicuddy et al. 1998, 2007), leading to changes in zooplankton community structure (Eden et al. 2009) as well as an increase in mesozooplankton biomass, enhanced fecal pellet flux, and increased carbon export by diel vertical migration (DVM) (Goldthwait \& Steinberg 2008). The goals of this study are to examine seasonal, interannual, and decadal patterns in the abundance of salp species in the Sargasso Sea and to determine the physical or biogeochemical conditions that lead to these patterns.

\section{MATERIALS AND METHODS}

\section{Salp collection}

Meszooplankton were collected as part of the Bermuda Atlantic Time-series Study (BATS) in the oligotrophic North Atlantic subtropical gyre $\left(31^{\circ} 40^{\prime} \mathrm{N}\right.$, $64^{\circ} 10^{\prime} \mathrm{W}$ ) (Madin et al. 2001, Steinberg et al. 2012). We identified and enumerated salps from $17 \mathrm{yr}$ of the time series. Overall, 776 tows were analyzed from 238 cruises from April 6, 1994 to November 11, 2011. Mesozooplankton tows were conducted using a net with a $0.8 \times 1.2 \mathrm{~m}$ rectangular mouth and $202 \mu \mathrm{m}$ mesh, with replicate, double-oblique tows made during day (09:00-15:00 h) and night (20:00-02:00 h) each month (May-January) or biweekly (February-April) (Madin et al. 2001, Steinberg et al. 2012). Targeted net depth was between 150 and 200 m, and actual depth was recorded using a Vemco Minilog recorder with the exception of the first year, when depth was estimated by wire out and wire angle. Volume filtered was measured using a General Oceanics flowmeter. Tow contents were immediately split on board with one half-split size-fractionated for total mesozooplankton biomass measurements, and the other half-split preserved in $4 \%$ buffered formaldehyde for taxonomic analysis (Madin et al. 2001, Steinberg et al. 2012).

\section{Salp enumeration and biomass determination}

Salps were analyzed from archived, preserved samples using an Olympus SZX-10 dissecting 
microscope at 6-10x magnification under dark and bright field illumination. Salps from the entire halfsplit or quarter-split were identified to species and enumerated, and the oral-atrial length of each salp was measured. Samples in which small salps (e.g. Thalia democratica) were very abundant $(>2000$ salps per tow) were subsampled using a $10 \mathrm{ml}$ Stempel pipette $(2.5 \mathrm{~cm}$ in diameter) after removal of any large salps. This subsample, and all large salps, were enumerated. At least 40 individuals of small salps, and all large salps, were measured to determine average length. Individual salp length was measured as the oral-atrial distance using an ocular micrometer, and these lengths were used in published salp live length to carbon weight regression equations for each species to calculate salp carbon biomass (see Table 5.3 in Madin \& Deibel 1998, and references therein). Total length of salps preserved in formaldehyde has been shown to decrease over time (Heron et al. 1988, Nishikawa \& Terazaki 1996). However, because this animal shrinkage is minimal and our preservation times varied, we did not correct salp length; thus, our carbon biomass estimates may be conservative. Salp data are presented as total salps, $T$. democratica, Salpa fusiformis, Weelia (Salpa) cylindrica, or Cyclosalpa polae abundance (density; ind. $\mathrm{m}^{-3}$ ) or carbon biomass $\left(\mathrm{mg} \mathrm{C} \mathrm{m}^{-3}\right)$.

\section{Comparison to environmental parameters and data analysis}

We examined potential environmental and climatological parameters influencing salp species abundance and biomass. For these analyses, salp biomass data for total salps and the 4 most abundant species on each sampling date were averaged between replicate tows and then between night and day. Average biomass for each sampling date was then compared to environmental data extracted from the BATS website (http://bats.bios. edu/) including sea-surface temperature (SST), water potential density, chl a integrated to $140 \mathrm{~m}$, and PP integrated to $140 \mathrm{~m}$ (Knap et al. 1997, Steinberg et al. 2001). The water-column stratification index (WCSI) was calculated as the difference in potential density between the surface and $200 \mathrm{~m}$ (Steinberg et al. 2012). Salp abundance was compared to the 12 mo centered moving average of the NAO (www.cpc.noaa.gov/products/precip/ CWlink/pna/nao/shtml), Multivariate El Niño Southern Oscillation (MEI) (www.esrl.noaa.gov/psd/people/
klaus.wolter/MEI/), North Pacific Gyre Oscillation (NPGO) (http://eros/eas/gatech/edu/npgo/), and Pacific Decadal Oscillation (PDO) (http://jisao. washington/edu/pdo/) indices as described in Steinberg et al. (2012). Salp biomass anomaly was calculated for each month using the following formula:

$$
A_{m}^{\prime}=\log _{10}\left[\frac{\bar{A}_{m}}{\bar{A}_{i}}\right]
$$

where $\bar{A}_{m}$ is the average biomass for year/month $m$, and $\bar{A}_{i}$ is the climatological median biomass for calendar month $i$. Annual biomass anomalies were then calculated as the average of $A_{m}^{\prime}$ for each year (Steinberg et al. 2012) and included total salps, T. democratica, $S$. fusiformis, and total salps minus $T$. democratica and $S$. fusiformis.

The Spearman rank correlation coefficient was used to compare salp abundance and biomass with environmental parameters, climate indices, and date to analyze seasonal and long-term changes. Monthly time series from April 1994 to November 2011 were constructed, with one observation per month, by averaging within months that contained more than one observation. Months with missing data $(\mathrm{n}=13$ out of 212) were assigned the median measured value of that calendar month, and the smallest nonzero observation for each species was added to all observations to eliminate zeroes. The time-series data were then natural-log transformed. After constructing the time series, each species and environmental data set was decomposed into its long-term trend (12 mo moving average), seasonal component (average of each calendar month after removing the long-term trend), and noise component (the remainder after removing both the long-term trend and seasonal component) using the time-series (ts) and decompose functions in R 2.13.0. The Spearman rank correlation coefficients were then calculated by comparing the extracted long-term trends of each variable, and the effective degrees of freedom used in calculating significance were adjusted for autocorrelation using Eq. (1) in Pyper \& Peterman (1998). In order to better examine the synergistic effects of different environmental variables on salp populations, correlations of seasonal and long-term trends were also compared using principal component analysis (PCA) in JMP 11.0.0. Bloom seasonality was analyzed by comparing the median bloom frequency between 2 seasonal periods within the year (e.g. February and March vs. the other 10 months of the year), and DVM was analyzed by comparing day and night salp abundance, both using the Mann-Whitney rank sum test. 


\section{Mesoscale eddies}

To examine the role that mesoscale eddies play in salp population dynamics, mesoscale eddy data in raw form were downloaded from the Cooperative Institute for Oceanographic Satellite Studies website (http://cioss.coas.oregonstate.edu/eddies/) (Chelton et al. 2011). This information included weekly eddy locations, rotation direction, amplitude, radius, and rotation speed. Using ESRI ArcGIS (version 10.0), we then determined which eddies were present at the BATS sampling location during tow sampling events. Only eddies with a total lifespan of $8 \mathrm{wk}$ or more were used. As eddy location was only given weekly, any eddy that overlapped the BATS sampling site within $110 \%$ of its circumference (our own estimate to include any eddy edge effect) within $6 \mathrm{~d}$ of the sampling date was considered present at the time of BATS sampling. The effect of eddy type and presence on salp biomass was evaluated using an ANOVA on ranks, the Bonferroni-Dunn test was used for pairwise comparisons, and correlations between salp biomass and eddy speed, amplitude, and radius were calculated using the Spearman rank correlation coefficient.

Additionally, eddy presence data were obtained from Mouriño-Carballido (2009), who determined eddy presence and type from 1993 to 2002 using both satellite altimetry and BATS hydrographic profiles. Mouriño-Carballido (2009) categorized eddy influence on the BATS site as cyclonic, anticyclonic, mode-water, none, or the frontal region between cyclonic and anticylconic eddies. For the purposes of our study, mode-water and anticyclonic eddies were combined into one 'anticyclonic' category, and frontal regions were delineated as no eddy present. A separate analysis was completed with these categorizations over the shorter time period, using an ANOVA on ranks to determine eddy influence on salp biomass.

\section{RESULTS}

\section{Species composition and seasonality}

In total, 21 species of salps were identified in the time series, with Thalia democratica, Salpa fusiformis, Weelia (Salpa) cylindrica, and Cyclosalpa polae being the most common species (present in tows from $77,61,21$, and $16 \%$ of the 238 monthly cruises, respectively) (Fig. 1, Table 1). Thalia democratica was the most abundant salp species and had the highest biomass, with average abundance across all samples of the time series in day and night tows of 3.31 and 1.90 ind. $\mathrm{m}^{-3}$, respectively, and biomass of 40.8 and $30.2 \mu \mathrm{g} \mathrm{C} \mathrm{m}^{-3}$, respectively. This was considerably higher than the second-most abundant and highest-biomass species, $S$. fusiformis, with an average abundance in day and night tows of $1.86 \times$ $10^{-3}$ and $2.56 \times 10^{-2}$ ind. $\mathrm{m}^{-3}$, respectively, and a biomass of 0.21 (day) and 3.39 (night) $\mu \mathrm{g} \mathrm{C} \mathrm{m}{ }^{-3}$ (Table 1). Total salp abundance and biomass was influenced mainly by $T$. democratica, although the other 20 species contributed relatively more to total biomass than abundance (Table 1), as T. democratica is one of the smallest salps in the region. Qualitatively, salps were highest in biomass during the spring (February-April) throughout the entire time series, with both early and late summer peaks (July-August) as well, particularly from 1999 to 2003 (Fig. 2).

Salp 'blooms' were defined as the top $10 \%$ of biomass observations within all non-zero observations for each species. The species analyzed for blooms were T. democratica, S. fusiformis, W. cylindrica, and C. polae. All of the bloom events were more than one order of magnitude greater than the median ( $T$. democratica and $S$. fusiformis) or mean ( $W$. cylindrica and C. polae; median was zero) biomass.

Salp blooms occurred regularly, with blooms of $T$. democratica, S. fusiformis, and C. polae occurring

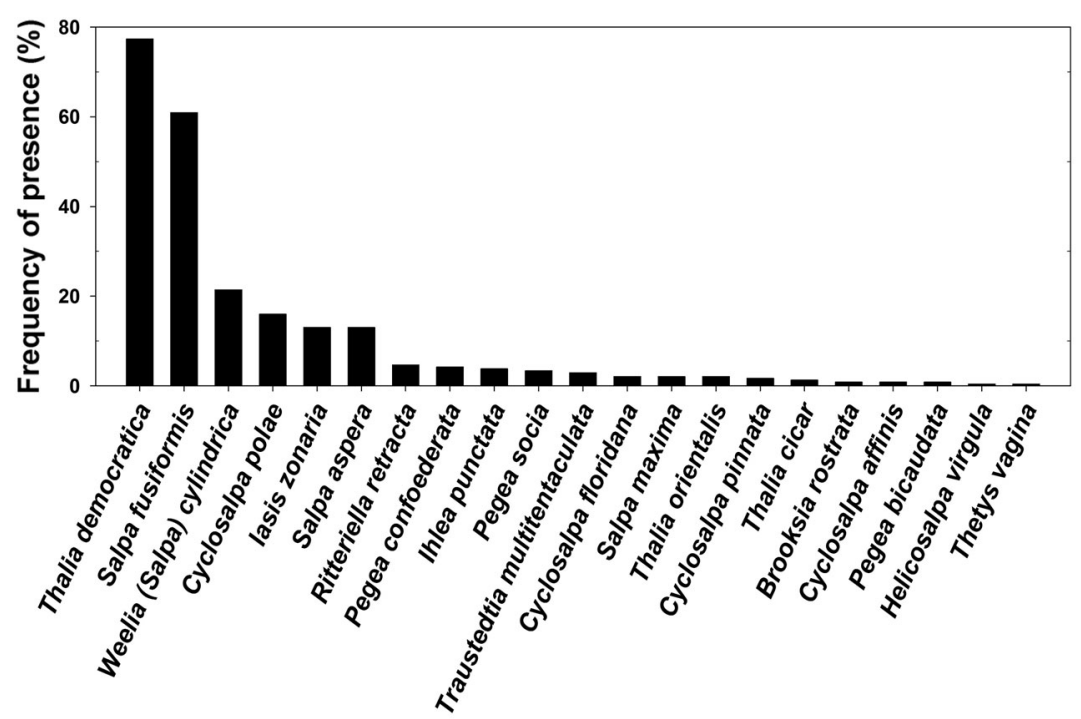

Fig. 1. Frequency of presence (as \%) of each salp species in monthly cruises $(n=238)$. A total of 776 tows were analyzed from all cruises between April 1994 and November 2011 
Table 1. Day $(n=227)$ and night $(n=222)$ biomass and abundance (mean \pm SD) for each salp species in the epipelagic zone at the Bermuda Atlantic Time-series Study (BATS) site. Mean and maximum day and night biomass and abundance are given for each species for the entire $17 \mathrm{yr}$ time series. Species are listed in decreasing order of frequency of presence (see Fig. 1). See 'Materials and methods' for biomass calculations

\begin{tabular}{|c|c|c|c|c|c|c|c|c|}
\hline \multirow[t]{2}{*}{ Species } & \multicolumn{4}{|c|}{ - Abundance (ind. $\mathrm{m}^{-3}$ ) } & \multicolumn{4}{|c|}{${ }_{-}$Biomass $\left(\mu \mathrm{g} \mathrm{C} \mathrm{m}^{-3}\right)$} \\
\hline & Day mean & Night mean & $\begin{array}{l}\text { Day } \\
\text { max. }\end{array}$ & $\begin{array}{l}\text { Night } \\
\text { max. }\end{array}$ & Day mean & Night mean & $\begin{array}{l}\text { Day } \\
\text { max. }\end{array}$ & $\begin{array}{l}\text { Night } \\
\text { max. }\end{array}$ \\
\hline Thalia democratica & $3.31 \pm 25.5$ & $1.90 \pm 17.5$ & 281 & 221 & $40.8 \pm 361$ & $30.2 \pm 245$ & 4470 & 2630 \\
\hline Salpa fusiformis & $1.86 \pm 7.35 \times 10^{-3}$ & $2.56 \pm 7.11 \times 10^{-2}$ & 0.073 & 0.962 & $0.211 \pm 1.24$ & $3.39 \pm 13.6$ & 14.1 & 178 \\
\hline Weelia (Salpa) cylindrica & $3.44 \pm 14.4 \times 10^{-3}$ & $6.32 \pm 30.9 \times 10^{-3}$ & 0.133 & 0.293 & $0.245 \pm 1.10$ & $0.587 \pm 4.40$ & 8.45 & 62.6 \\
\hline Salpa aspera & $4.24 \pm 40.1 \times 10^{-4}$ & $1.41 \pm 10.3 \times 10^{-2}$ & 0.054 & 1.44 & $0.034 \pm 0.347$ & $3.77 \pm 15.4$ & 4.07 & 136 \\
\hline Ritteriella retracta & $6.09 \pm 64.9 \times 10^{-5}$ & $1.03 \pm 7.67 \times 10^{-3}$ & 0.007 & 0.098 & $0.057 \pm 0.836$ & $0.202 \pm 1.29$ & 12.6 & 12.6 \\
\hline Pegea confoederata & $1.23 \pm 11.7 \times 10^{-3}$ & $1.69 \pm 17.5 \times 10^{-3}$ & 0.143 & 0.239 & $0.298 \pm 3.11$ & $0.242 \pm 2.53$ & 44.4 & 35.8 \\
\hline Ihlea punctata & $4.04 \pm 41.2 \times 10^{-4}$ & $8.05 \pm 62.3 \times 10^{-4}$ & 0.053 & 0.071 & $0.035 \pm 0.396$ & $0.134 \pm 1.02$ & 5.69 & 12.6 \\
\hline Pegea socia & $8.34 \pm 83.3 \times 10^{-4}$ & $2.57 \pm 20.7 \times 10^{-4}$ & 0.114 & 0.023 & $1.10 \pm 14.1$ & $0.148 \pm 1.64$ & 210 & 23.7 \\
\hline Traustedtia multitentaculata & $1.84 \pm 13.6 \times 10^{-4}$ & $2.53 \pm 27.8 \times 10^{-4}$ & 0.015 & 0.040 & $0.019 \pm 0.232$ & $0.017 \pm 0.200$ & 3.45 & 2.90 \\
\hline Thalia cicar & $2.29 \pm 34.5 \times 10^{-5}$ & $7.04 \pm 75.2 \times 10^{-5}$ & 0.005 & 0.009 & $0.001 \pm 0.018$ & $0.001 \pm 0.020$ & 0.27 & 0.30 \\
\hline Brooksia rostrata & $3.16 \pm 47.6 \times 10^{-5}$ & $6.32 \pm 94.1 \times 10^{-5}$ & 0.007 & 0.014 & 0.000 & $0.014 \pm 0.215$ & 0.07 & 3.20 \\
\hline Cyclosalpa affinis & $1.96 \pm 29.6 \times 10^{-4}$ & $2.86 \pm 42.6 \times 10^{-5}$ & 0.045 & 0.006 & $0.001 \pm 0.009$ & $0.003 \pm 0.050$ & 0.14 & 0.75 \\
\hline Pegea bicaudata & $2.48 \pm 37.4 \times 10^{-5}$ & $5.33 \pm 79.4 \times 10^{-4}$ & 0.006 & 0.118 & $0.002 \pm 0.028$ & $0.061 \pm 0.907$ & 0.42 & 13.5 \\
\hline Helicosalpa virgula & 0.00 & $1.64 \pm 24.4 \times 10^{-5}$ & 0.000 & 0.004 & 0.000 & $0.001 \pm 0.016$ & 0.00 & 0.24 \\
\hline Thetys vagina & 0.00 & $1.83 \pm 27.3 \times 10^{-5}$ & 0.000 & 0.004 & 0.000 & $0.015 \pm 0.222$ & 0.00 & 3.31 \\
\hline
\end{tabular}

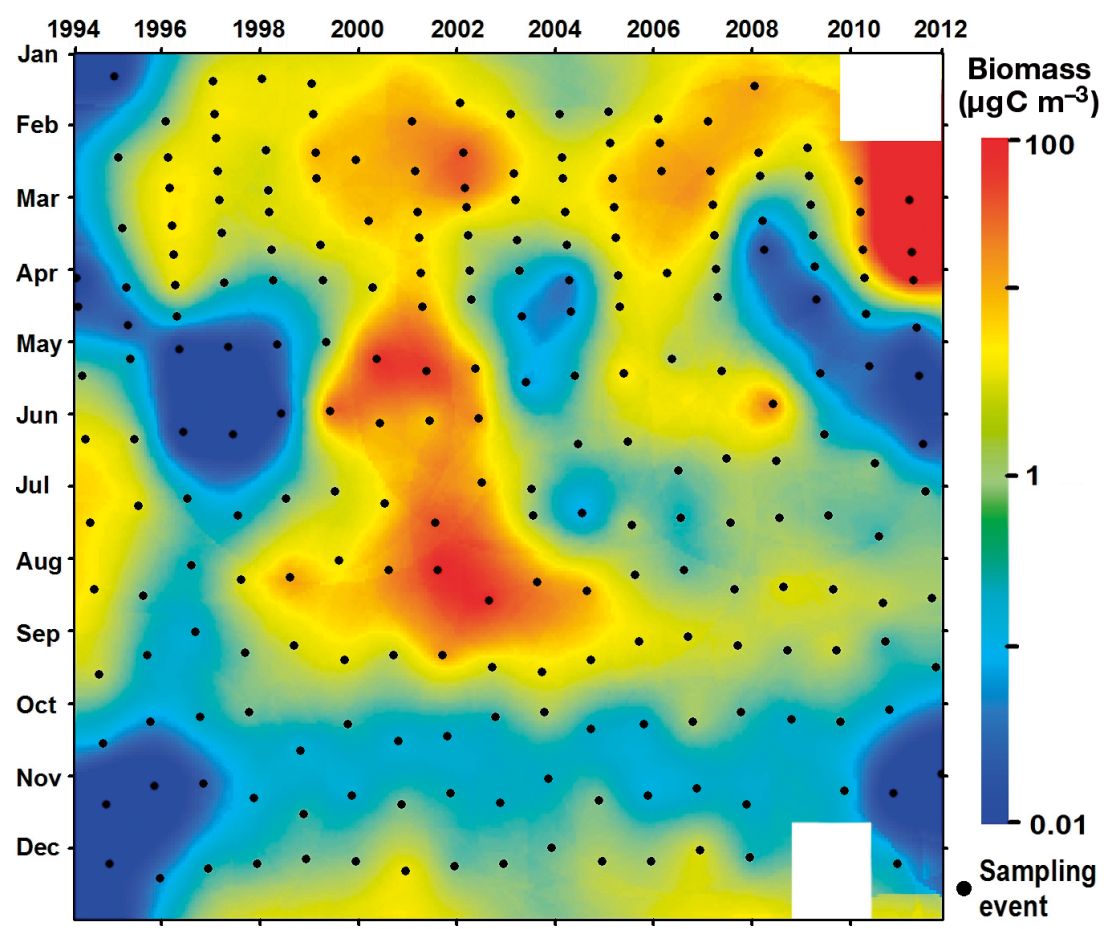

Fig. 2. Seasonal and interannual total salp biomass at the Bermuda Atlantic Timeseries Study (BATS) site. Total combined (all species) salp biomass across the time series (April 1994-November 2011). Note that biomass is depicted on a log scale and areas with low temporal coverage have been whited-out more often in February and March, with a median total of $5.5,4$, and 1 bloom, respectively, in each of those months over the time series (Fig. 3A). The occurrence of blooms in those 2 months was significantly higher than the median occurrence in the other 10 months of the year $(\mathrm{p}<0.05$; Mann-Whitney rank sum test). $W$. cylindrica blooms occurred more commonly in late summer (median total of 1 bloom in each of July, August, and September) compared with the rest of the year $(p=0.002)$. Blooms in all other species combined were evenly distributed throughout the year. Monthly averages of salp biomass with the long-term trend removed showed similar seasonal patterns with $T$. democratica, $S$. fusiformis, and C. polae peaking in the spring, $W$. cylindrica peaking in late summer, and all others remaining relatively constant throughout the year (Fig. 3B). 


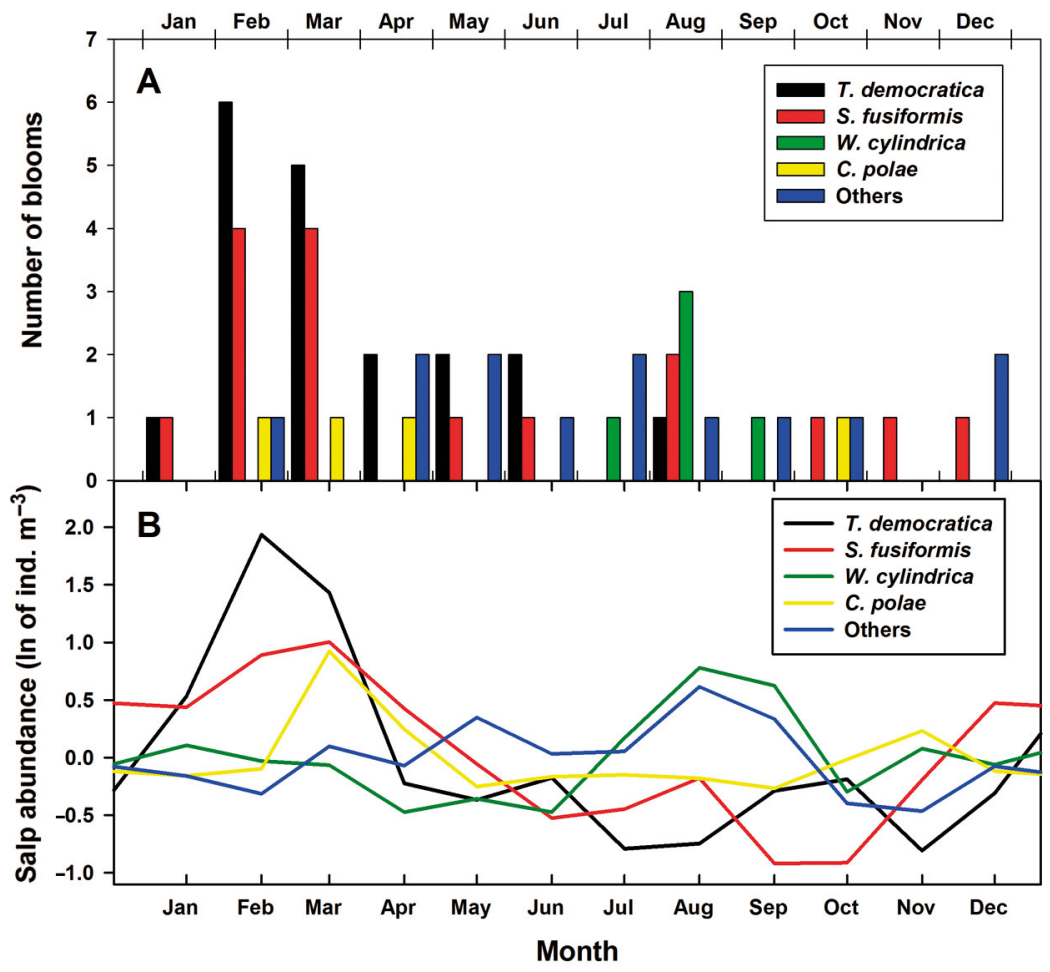

Fig. 3. Monthly distribution of (A) salp blooms and (B) average monthly abundance after removal of the long-term trend. Shown are the sums of all blooms in each month for the 4 most abundant species - Thalia democratica, Salpa fusiformis, Weelia (Salpa) cylindrica, and Cyclosalpa polae, and all other salps combined over the entire time series (April 1994-November 2011) waters at night compared to during the day, but also 12 blooms with at least 2-fold higher biomass in the surface waters during the day than at night. For most other species, presence in tows was too infrequent or biomass likely too low for a significant difference between day and night to be detected.

\section{Mesoscale eddies}

A total of 56 mesoscale eddies were detected intersecting the BATS site within $6 \mathrm{~d}$ of a zooplankton sampling event from April 1994 to November 2011, using the Chelton and Schlax eddy data set. Of these 56 eddies, 38 were cyclonic and 18 were anticyclonic; there was no significant difference between the median amplitude, speed, and radius of the 2 eddy types (Table 2). When comparing median abundance of $T$. democratica between cyclonic, anticyclonic, and no eddies, there was a significant difference between treatments $(p=0.017)$, but there were no significant differences in pairwise comparisons. However, the median biomass of T. democ-

\section{Diel vertical migration}

Of the 21 salp species present, 5 exhibited a detectable pattern of DVM, with significantly higher median biomass during the night than during the day (Fig. 4). These diel vertical migrators included 2 species of Salpa (S. fusiformis, $\mathrm{n}=136, \mathrm{p}<0.001 ; S$. aspera, $\mathrm{n}=30, \mathrm{p}<0.001), W$. cylindrica $(\mathrm{n}=48, \mathrm{p}=0.030)$, Iasis zonaria ( $\mathrm{n}=31, \mathrm{p}<0.001)$, and Ritteriella retracta $(\mathrm{n}=11, \mathrm{p}=0.002)$. Overall, T. democratica did not demonstrate DVM (Fig. 4), with day median biomass $\left(0.342 \mu \mathrm{g} \mathrm{C} \mathrm{m}^{-3}\right)$ not significantly different from night median biomass $\left(0.362 \mu \mathrm{g} \mathrm{C} \mathrm{m}^{-3} ; \mathrm{n}=165, \mathrm{p}=\right.$ 0.899). When at bloom concentrations, we did detect day-night differences in $T$. democratica, with 6 blooms (out of 33) having at least 2-fold higher biomass in surface

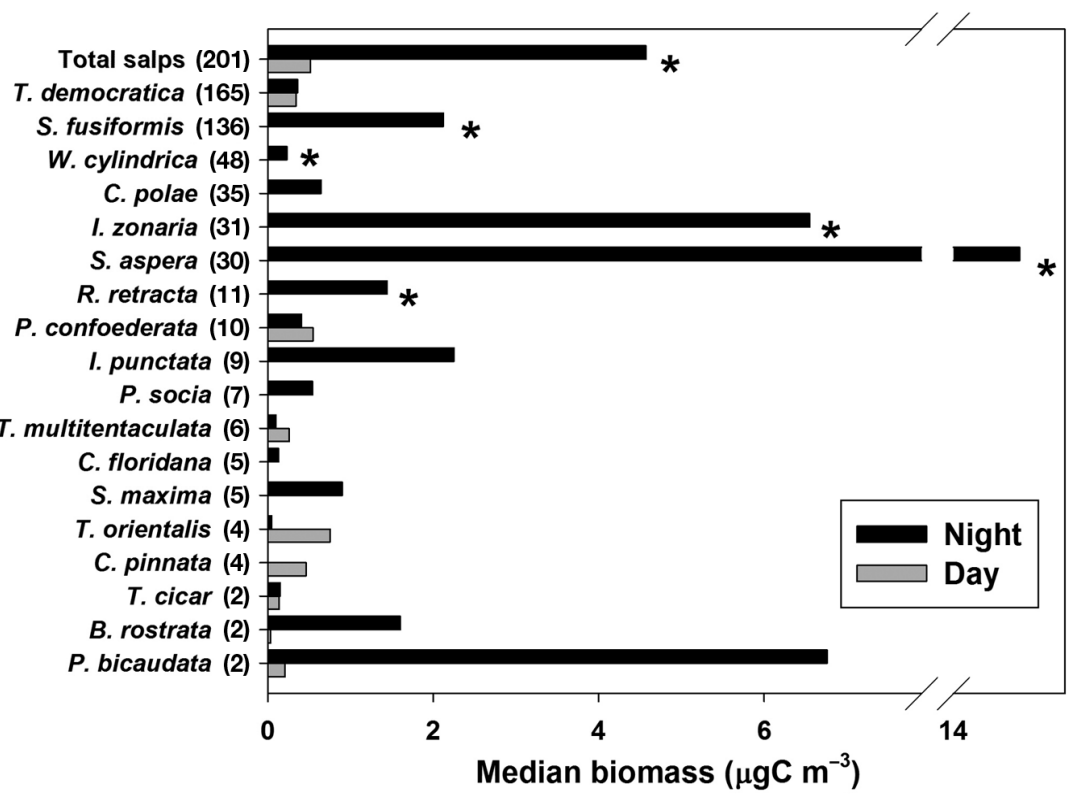

Fig. 4. Salp diel vertical migration. Day and night median biomass of total salps and 18 species of salps at the Bermuda Atlantic Time-series Study (BATS) site across the time series (April 1994-November 2011). Day and night biomasses that are significantly different (i.e. the species demonstrates diel vertical migration) are marked with an asterisk; the number of day-night observation pairs for each species is in parentheses. Full species names given in Fig. 1 
ratica was significantly higher within cyclonic eddies $\left(0.609 \mu \mathrm{g} \mathrm{C} \mathrm{m}^{-3}\right)$ than within anticyclonic eddies (0.129 $\mu \mathrm{g} \mathrm{C} \mathrm{m}^{-3}$; Fig. 5). Within the 38 cyclonic eddies, T. democratica biomass was not significantly correlated with eddy rotational speed or amplitude. No significant relationships between other salp species and eddy presence, type, or attributes were found.

Table 2. Mean $( \pm \mathrm{SD})$ and range for the amplitude, rotation speed, and radius of the 56 mesoscale eddies that passed through the Bermuda Atlantic Time-series Study (BATS) site within $6 \mathrm{~d}$ of a zooplankton sampling event. Eddies were considered to have passed through the BATS site if $110 \%$ of their circumference encompassed the BATS site. Eddy data were collected from the online database http://cioss.coas. oregonstate.edu/eddies/ (Chelton et al. 2011)

\begin{tabular}{|lcc|}
\hline & Cyclonic & Anticyclonic \\
\hline Number & 38 & 18 \\
Mean amplitude $(\mathrm{cm})$ & $8.0 \pm 4.4$ & $8.1 \pm 2.8$ \\
Amplitude range $(\mathrm{cm})$ & $1.2-16.5$ & $4.2-14.2$ \\
Mean rotational speed $\left(\mathrm{cm} \mathrm{s}^{-1}\right)$ & $17.0 \pm 6.4$ & $17.5 \pm 3.8$ \\
Rotational speed range $\left(\mathrm{cm} \mathrm{s}^{-1}\right)$ & $7.1-33.9$ & $13.1-26.6$ \\
Mean radius $(\mathrm{km})$ & $96 \pm 22.2$ & $104 \pm 29.5$ \\
Radius range $(\mathrm{km})$ & $54-148$ & $66-159$ \\
\hline
\end{tabular}

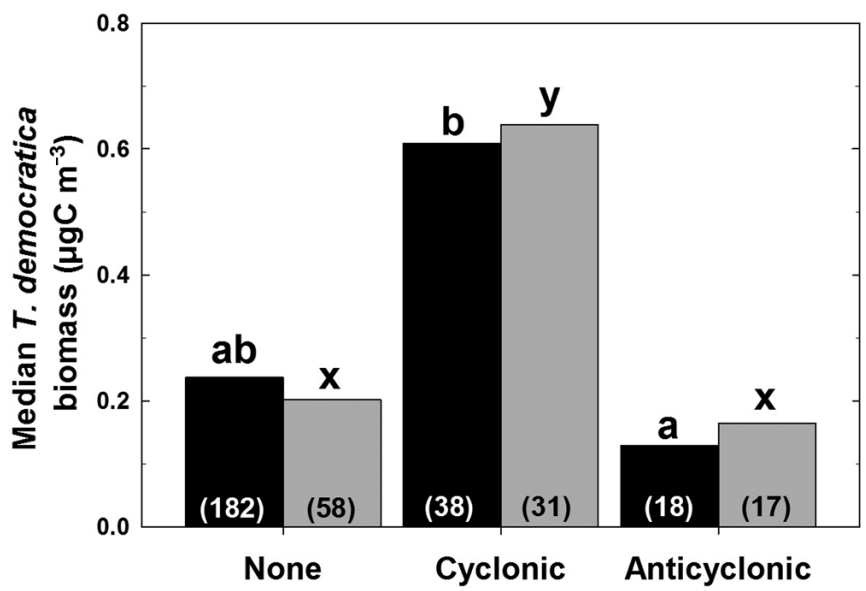

Fig. 5. Median biomass of Thalia democratica within cyclonic and anticyclonic eddies, and when no eddies are present, at the Bermuda Atlantic Time-series Study (BATS) site. Black bars represent salp median biomass for eddies from the Chelton and Schlax database (http://cioss.coas. oregonstate.edu/eddies/) that encompassed the BATS site within $110 \%$ of their circumference within $6 \mathrm{~d}$ of a zooplankton sampling event and represents our entire salp time series (April 1994-November 2011). Gray bars represent salp median biomass for eddies listed in Mouriño-Carballido (2009) that influenced BATS from April 1994 to December 2001. Numbers in parentheses indicate the number of eddy-influenced samples within each category. Bars with different letters are significantly different (Bonferroni-Dunn test, $\mathrm{p}<0.05$ ) from other bars within that database (' $\mathrm{a}$ ' and ' $\mathrm{b}$ ' for Chelton and Schlax, and ' $\mathrm{x}$ ' and ' $\mathrm{y}$ ' for MouriñoCarballido)
Using the Mouriño-Carballido (2009) eddy determinations, a total of 48 sampling events between April 1994 and December 2001 were eddy influenced, with 31 cyclonic eddies and 17 anticyclonic eddies. The median biomass of $T$. democratica was significantly higher within cyclonic eddies $(0.638 \mu \mathrm{g}$ $\left.\mathrm{C} \mathrm{m}^{-3}\right)$ than within anticyclonic eddies $(0.165 \mu \mathrm{g} \mathrm{C}$ $\left.\mathrm{m}^{-3}\right)$ or in the absence of eddies $\left(0.202 \mu \mathrm{g} \mathrm{C} \mathrm{m}{ }^{-3}\right.$; Fig. 5). No significant relationships between other salp species and eddy presence or type were found.

\section{Long-term trends}

There was no significant long-term positive or negative trend in total salp biomass over the $17 \mathrm{yr}$ time series; however, over the time series there were weak, but significant, increases in both $T$. democratica and C. polae biomass, and in WCSI (Fig. 6A, B, and C, respectively). The linear increase in WCSI is due to both a significant increase in SST and a coinciding decrease in temperature from 300 to $600 \mathrm{~m}$ depth $\left(\mathrm{R}^{2}=0.25\right.$, $\mathrm{p}<$ 0.0001 , for both) over the time series. The increases in salp biomass were log-linear and represented an increase of $0.01 \mu \mathrm{g} \mathrm{C} \mathrm{m}^{-3} \mathrm{yr}^{-1}$ for T. democratica and $0.003 \mu \mathrm{g} \mathrm{C} \mathrm{m}^{-3} \mathrm{yr}^{-1}$ for C. polae. Mean annual biomass anomalies for T. democratica (Fig. 7B) were consistently positive over the last 6 yr of the time series, and for $S$. fusiformis were strongly negative over the last $4 \mathrm{yr}$ (Fig. 7C). Additionally, there was a distinct shift after $2000(t=-3.413, \mathrm{p}=0.004)$ from consistently negative to positive anomalies in total salps other than T. democratica and S. fusiformis (Fig 7D).

Additionally, a cyclical pattern in T. democratica biomass was evident, with average annual biomass increasing by $3-7$ orders of magnitude every 3 yr (Fig. 8). This cycle is supported by the spectral density of the $T$. democratica biomass long-term trend, which was highest in value at a period of $33.3 \mathrm{mo}$ (Fig. 8, inset). This pattern is mostly driven by larger spring blooms of $T$. democratica during these peak years, but also by elevated biomass throughout the year, and occasional non-spring blooms.

\section{Environmental and climate influences}

Total salp seasonality was most closely grouped with integrated PP in the PCA of seasonality in salps and environmental parameters (Fig. 9A). Additionally, T. democratica and $S$. fusiformis were closely grouped with PP and chl a concentrations. These 2 species were also seasonally negatively correlated 


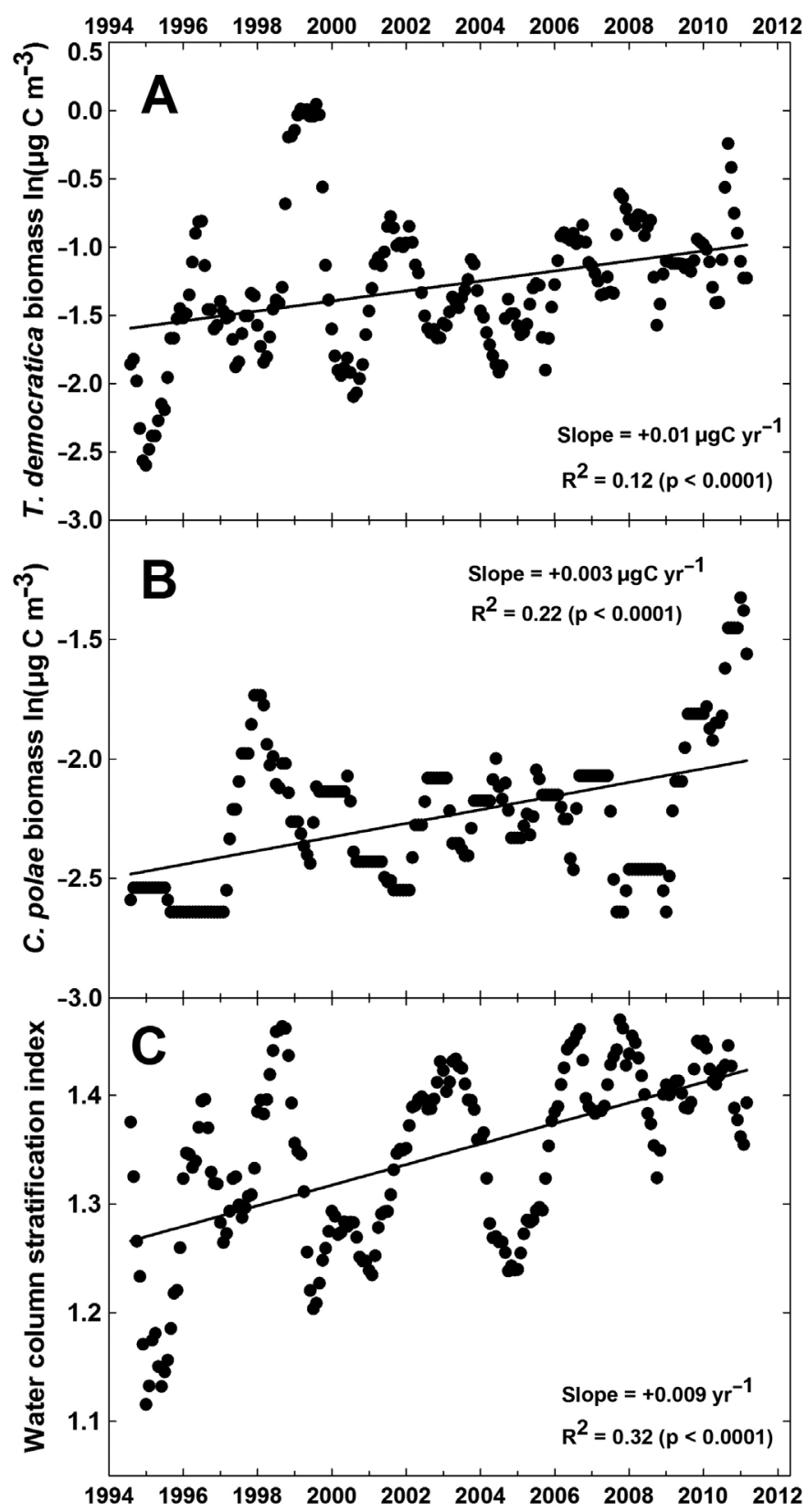

Fig. 6. Twelve month moving average of (A) Thalia democratica biomass, (B) Cyclosalpa polae biomass, and (C) the water column stratification index (WCSI) across the time series (October 1994-May 2011). Note the natural log scale for the salp biomass plots. All regressions are log-linear

with SST and the WCSI. C. polae was weakly negatively correlated with SST and the WCSI. W. cylindrica and all salps other than the 'top' (highest biomass) 4 species grouped together, and were most strongly, and negatively, correlated with 300-600 m water temperature, although this only explained a small portion of their variability.
Long-term trends in salp biomass were significantly correlated with several environmental parameters (Table 3, Fig. 9B). However, the variance explained by components 1 and 2 of the PCA (Fig. 9B) is low, suggesting a complex system poorly represented by the first 2 components alone. Both SST and the WCSI were positively correlated with $T$. democratica and C. polae biomass (Table 3). Additionally, $T$. democratica and C. polae were positively correlated with SST in the PCA (Fig. 9B). PP was negatively correlated with biomass of $S$. fusiformis, C. polae, and $W$. cylindrica (Table 3 ), but strongly positively correlated with total salp and $T$. democratica abundance (Table 3, Fig. 9B). Integrated chl a was negatively correlated with $W$. cylindrica and weakly so with biomass of less abundant salp species (Table 3). Chl a was positively correlated with $C$. polae biomass and abundance and $S$. fusiformis abundance (Table 3). Lower mesopelagic temperatures corresponded with higher biomass of total salps, T. democratica, $S$. fusiformis, C. polae, and other less abundant species (Table 3).

We compared the long-term trend of biomass of total salps, T. democratica, S. fusiformis, W. cylindrica, C. polae, and all other salp species combined with the 12 mo moving average of 4 decadal climate indices (Table 4, Fig. 10). Total salp biomass was most strongly, and positively, correlated with the NPGO (Fig. 10A). T. democratica was most strongly, and negatively, correlated with the PDO (Fig. 10B). $S$. fusiformis was significantly positively correlated with the PDO (Fig. 10C), while all other salps combined was most strongly positively correlated with the NPGO (Fig. 10D). Significant correlations between other salp species and climate indices can be found in Table 4.

\section{DISCUSSION}

\section{Salp species composition and seasonality}

We found a total of 21 species of salps present in the entire time series, compared to 16 species over 2 cruises in late summer and spring of 1989-1990 (Madin et al. 1996) and 20 species throughout the year in 1967-1972 (van Soest 1975) in the BATS region. Of the 25 salp species van Soest (1998) reported to occur throughout the northwestern Atlantic Ocean, only 4 species were not present at the BATS site: Salpa younti, Brooksia bermeri, Cyclosalpa bakeri, and C. foxtoni. The most common species at the BATS site were Thalia democrat- 


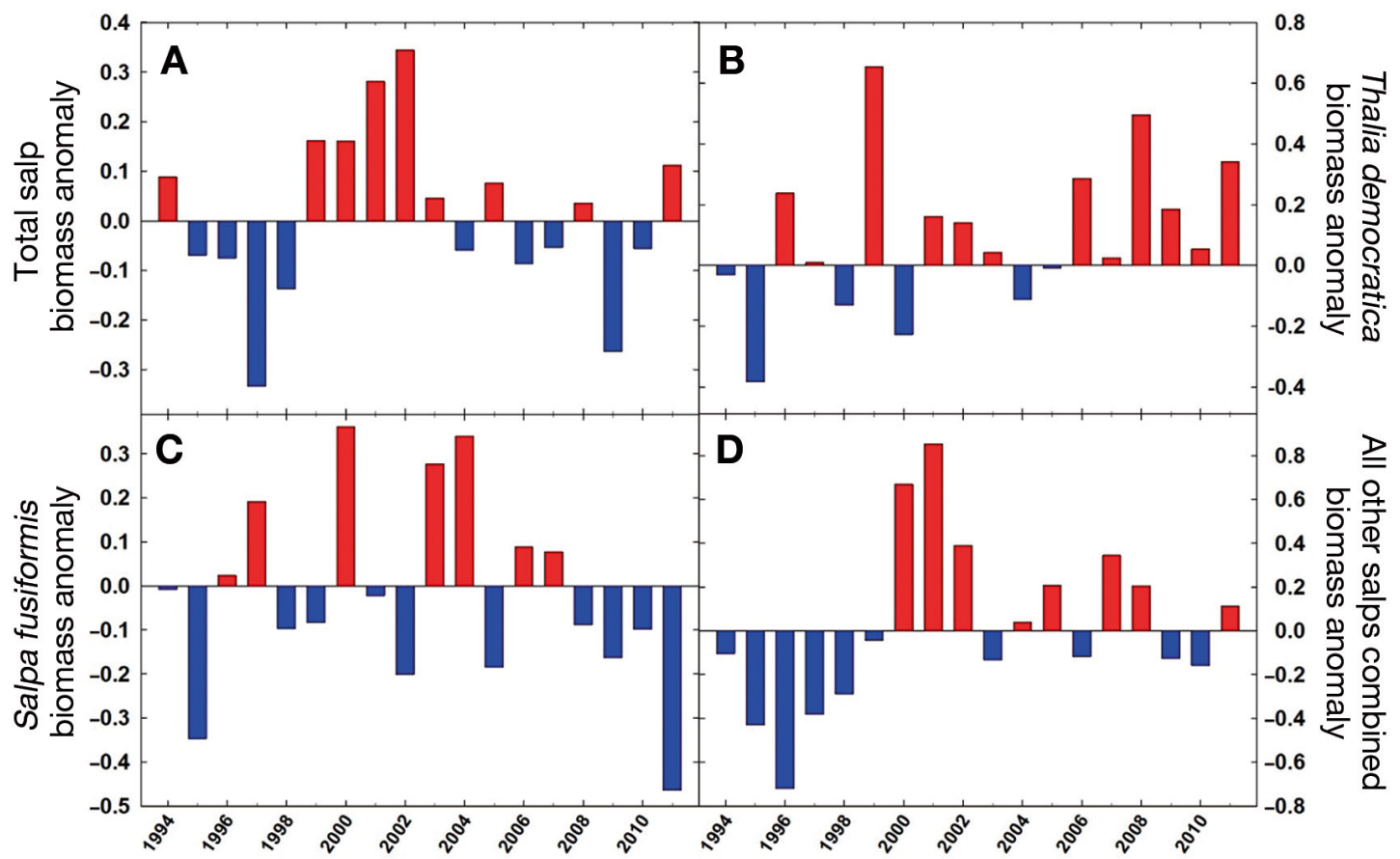

Fig. 7. Yearly average biomass anomaly for (A) total salps, (B) Thalia democratica, (C) Salpa fusiformis, and (D) total salps minus $T$. democratica and S. fusiformis. Red and blue bars indicate higher and lower biomass, respectively, for that year compared to the annual median of the whole time series

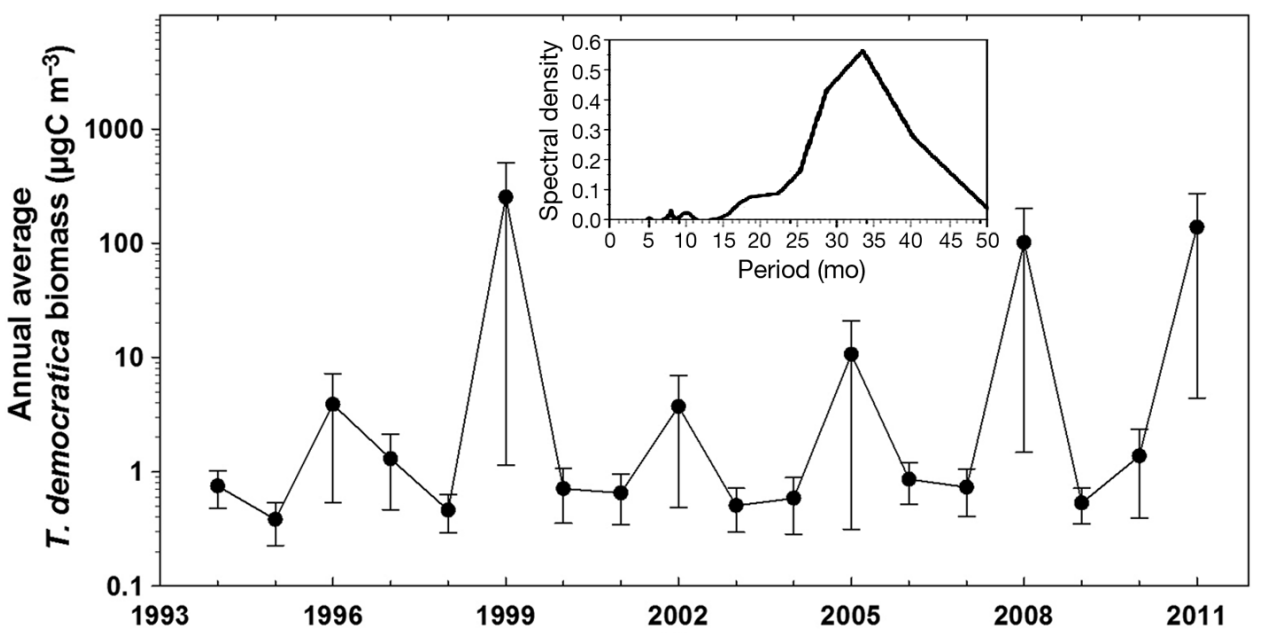

Fig. 8. Annual average biomass of Thalia democratica. Monthly averages were calculated first to avoid bias towards the more frequently sampled spring period, and the median monthly value of each month was used for missing data points. Error bars represent standard error. Note natural log scale and the cycle of higher average biomass every 3 yr. Inset is the calculated spectral density of the monthly time series 12 mo moving average showing the most significant periodicity

ica and S. fusiformis, with other species such as Weelia (Salpa) cylindrica, C. polae, Iasis zonaria, and $S$. aspera seasonally abundant. While van Soest (1975) and Madin et al. (1996) did not measure absolute abundance of salps, the relative abundances of species that they observed were similar to those we found. In the BATS time series, total salp abundance reached as high as 371 ind. $\mathrm{m}^{-3}$ (during a $T$. democratica bloom), which is comparable to documented maxima of 150 ind. $\mathrm{m}^{-3}$ for the Bay of Bengal (Madhupratap et al. 1980), 300 ind. $\mathrm{m}^{-3}$ for the Agulhas Bank (Gibbons 1997), and 100 ind. $\mathrm{m}^{-3}$ in the South Atlantic Bight of the USA (Paffenhöfer \& Lee 1987). However, this is lower than off south- 


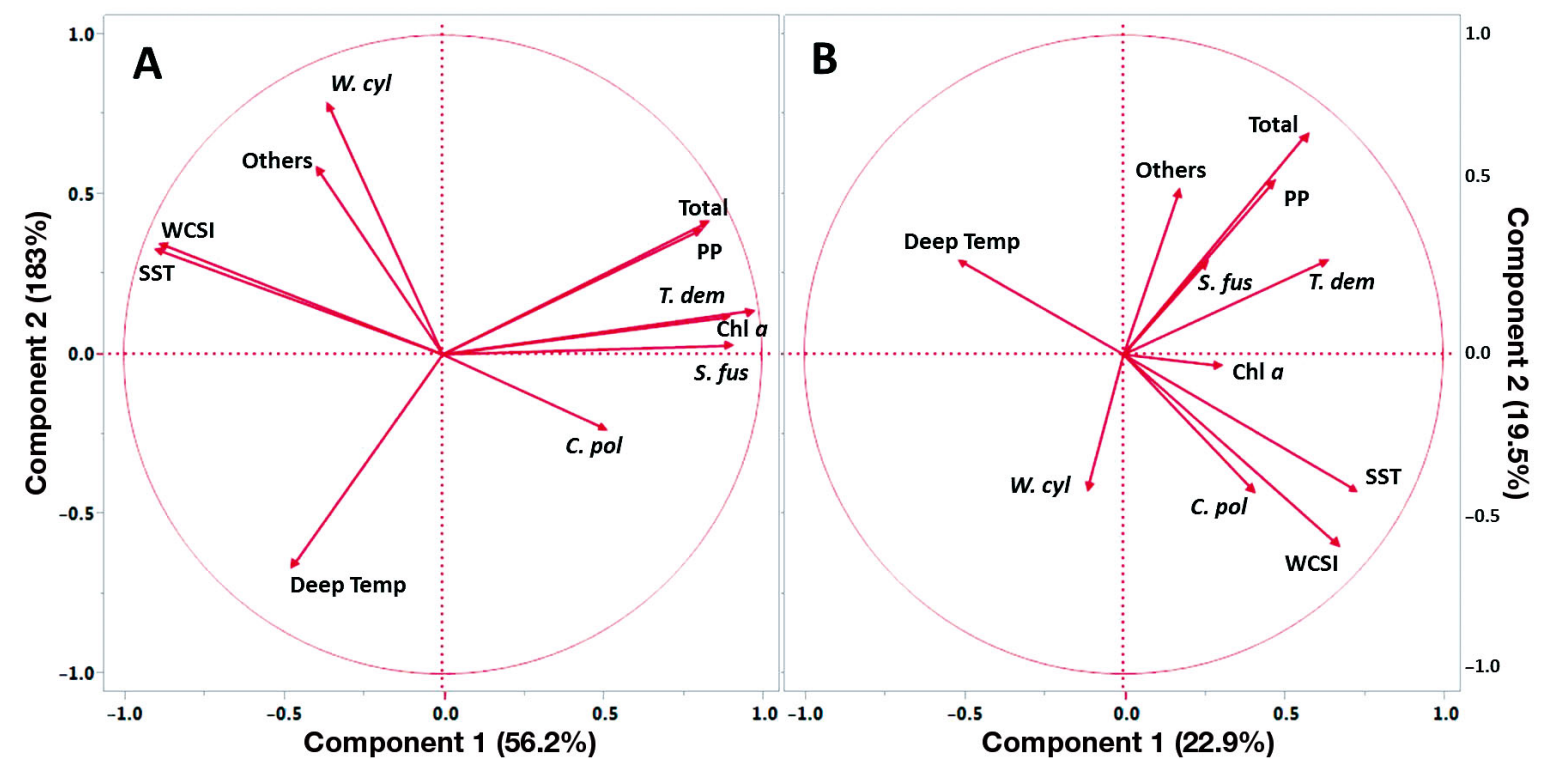

Fig. 9. Principal component analysis of salp biomass and environmental parameters for (A) seasonal averages after removing the long-term trend and (B) the long-term trend. Total: total salps; T. dem: Thalia democratica; S. fus: Salpa fusiformis; C. pol: Cyclosalpa polae; W. cyl: Weelia (Salpa) cylindrica; Others: all other salp biomass combined; PP: primary production integrated to $140 \mathrm{~m}$; Chl a: chlorophyll a integrated to $140 \mathrm{~m}$; WCSI: water column stratification index; SST: sea surface temperature; Deep Temp: mean temperature in mesopelagic zone from 300 to $600 \mathrm{~m}$

east Australia, where abundance exceeded 2444 ind. $\mathrm{m}^{-3}$ for $T$. democratica in a bloom event within an eddy (Henschke et al. 2011). The second most common species, S. fusiformis, reached 0.96 ind. $\mathrm{m}^{-3}$, which is comparable to a $S$. fusiformis maximum of 1.6 ind. $\mathrm{m}^{-3}$ in coastal Taiwan (Tew \& Lo 2005) and 2 ind. $\mathrm{m}^{-3}$ in the Humboldt Current (González et al. 2000). But this is much lower than $\sim 700 \mathrm{~S}$. fusiformis ind. $\mathrm{m}^{-3}$ found in the North Atlantic west of Ireland (Bathmann 1988) and 225 ind. $\mathrm{m}^{-3}$ off northwest Spain (Huskin et al. 2003).
There was a distinct seasonality in salp blooms, with 3 of the 4 most abundant species ( $T$. democratica, S. fusiformis, and C. polae) blooming more commonly in February and March (spring), coinciding with the seasonal increase in primary production and chlorophyll biomass (Steinberg et al. 2001, Lomas et al. 2013). In contrast, W. cylindrica bloomed more frequently in late summer, suggesting that other processes are responsible for their rapid population increase. Similarly, Madin et al. (1996) found $W$. cylindrica present in August but absent in March and

Table 3. Spearman correlation coefficients for the 12 mo moving average of salp abundance (ind. $\mathrm{m}^{-3}$ ) and biomass $\left(\mu \mathrm{g} \mathrm{C} \mathrm{m}^{-3}\right.$ ) versus environmental parameters. Not significant (NS); $\mathrm{p} \geq 0.05 ;{ }^{*} 0.05>\mathrm{p} \geq 0.01 ;{ }^{* *} 0.01>\mathrm{p} \geq 0.001 ;{ }^{* * *} \mathrm{p}<0.001$

\begin{tabular}{|c|c|c|c|c|c|}
\hline Species & $\begin{array}{l}\text { Sea surface } \\
\text { temperature }\end{array}$ & $\begin{array}{l}\text { Water column } \\
\text { stratification } \\
\text { index }\end{array}$ & $\begin{array}{l}\text { Temperature } \\
300 \text { to } 600 \mathrm{~m}\end{array}$ & $\begin{array}{l}\text { Primary production } \\
\text { integrated to } 140 \mathrm{~m}\end{array}$ & $\begin{array}{c}\text { Chlorophyll a } \\
\text { integrated } \\
\text { to } 140 \mathrm{~m}\end{array}$ \\
\hline Total salp abundance & NS & NS & NS & $0.42^{* * *}$ & NS \\
\hline Total salp biomass & NS & NS & $-0.23^{* *}$ & $0.18^{*}$ & NS \\
\hline Thalia democratica abundance & NS & $0.20^{*}$ & $-0.24^{* *}$ & $0.32^{* * *}$ & NS \\
\hline Thalia democratica biomass & $0.23^{* *}$ & $0.48^{* * *}$ & $-0.43^{* * *}$ & $0.22^{* *}$ & NS \\
\hline Salpa fusiformis abundance & NS & NS & $-0.29^{* * *}$ & NS & $0.20^{*}$ \\
\hline Salpa fusiformis biomass & NS & NS & $-0.36^{* * *}$ & $-0.19^{* *}$ & NS \\
\hline Weelia (Salpa) cylindrica abundance & NS & NS & NS & $-0.30^{* * *}$ & $-0.32^{* * *}$ \\
\hline Weelia (Salpa) cylindrica biomass & NS & NS & NS & $-0.38^{* *}$ & $-0.23^{* * *}$ \\
\hline Cyclosalpa polae abundance & $0.34^{* * *}$ & $0.29^{* * *}$ & NS & NS & $0.20^{* *}$ \\
\hline Cyclosalpa polae biomass & $0.31^{* * *}$ & $0.30^{* * *}$ & $-0.16^{*}$ & $-0.16^{*}$ & $0.24^{* * *}$ \\
\hline Others combined abundance & NS & NS & NS & NS & NS \\
\hline Others combined biomass & NS & NS & $-0.19^{*}$ & NS & $-0.20^{*}$ \\
\hline
\end{tabular}


Table 4. Spearman correlation coefficients for the 12 mo moving average of climate index anomalies versus the 12 mo moving average of salp biomass and abundance. MEI: Multivariate El Niño Southern Oscillation; NAO: North Atlantic Oscillation; NPGO: North Pacific Gyre Oscillation; PDO: Pacific Decadal Oscillation. Not significant (NS); $\mathrm{p} \geq 0.05$; $^{*} 0.05>\mathrm{p} \geq 0.01 ;{ }^{* *} 0.01>$ $\mathrm{p} \geq 0.001 ;{ }^{* * *} \mathrm{p}<0.001$

\begin{tabular}{|lcccc|}
\hline Species & MEI & NAO & NPGO & PDO \\
\hline Total salp abundance & $-0.40^{* * *}$ & NS & $0.55^{* * *}$ & $-0.37^{* * *}$ \\
Total salp biomass & $-0.22^{* *}$ & $0.20^{* *}$ & $0.57^{* * *}$ & $-0.45^{* * *}$ \\
Thalia democratica abundance & $-0.44^{* * *}$ & NS & $0.28^{* * *}$ & $-0.35^{* * *}$ \\
Thalia democratica biomass & $-0.44^{* * *}$ & NS & $0.40^{* * *}$ & $-0.54^{* * *}$ \\
Salpa fusiformis abundance & NS & NS & NS & $0.25^{* *}$ \\
Salpa fusiformis biomass & NS & NS & NS & $0.27^{* * *}$ \\
Weelia (Salpa) cylindrica abundance & NS & NS & NS & NS \\
Weelia (Salpa) cylindrica biomass & NS & NS & NS & NS \\
Cyclosalpa polae abundance & NS & $-0.33^{* * *}$ & $0.26^{* * *}$ & NS \\
Cyclosalpa polae biomass & NS & $-0.32^{* * *}$ & $0.22^{* *}$ & NS \\
Others combined abundance & NS & $0.25^{* * *}$ & $0.47^{* * *}$ & $-0.25^{* *}$ \\
Others combined biomass & NS & $0.38^{* * *}$ & $0.46^{* * *}$ & $-0.27^{* *}$ \\
\hline
\end{tabular}

April, although van Soest (1975) found W. cylindrica present in low abundances year-round. Other salp species were more variable in their bloom seasonality and showed no overall trend.

\section{Environmental influences}

Environmental parameters such as SST and water column stratification (which in turn influence mixing and PP) are important seasonal regulators of salp abundance at BATS. The BATS region is characterized by a spring phytoplankton bloom in JanuaryMarch that follows a period of winter mixing (Steinberg et al. 2001). Abundance and biomass of 3 of the 4 most common species of salps at BATS ( $T$. democratica, S. fusiformis, and C. polae) respond to this seasonal bottom-up forcing, as shown by the increase in their abundance with increasing chl $a$ and $\mathrm{PP}$, and the more frequent occurrence of blooms in early spring than at other times of the year. Correspondingly, seasonally lower SST and reduced stratification, typical of conditions at the onset of the spring bloom, result in higher abundance of these 3 salp species. This response of salps to the spring phytoplankton bloom is similar to that in other systems, including T. democratica off the southern Atlantic coast of the USA (Deibel \& Paffenhöfer 2009) and in the Tasman Sea (Heron 1972), S. fusiformis off northwestern Spain (Huskin et al. 2003), and both T. democratica and S. fusiformis in the western Mediterranean Sea (Ménard et al. 1994). In some coastal systems, the correlation between chl $a$ and salp abundance becomes negative at very high chl a concentrations (Zeldis et al. 1995, Liu et al.
2012), presumably due to the clogging of the salp's mucous feeding net (i.e. at chl a concentrations $>1 \mu \mathrm{g} \mathrm{l}^{-1}$; Harbison et al. 1986). However, phytoplankton biomass in the oligotrophic BATS region, typically ranging from 0 to 0.8 $\mu \mathrm{g} \mathrm{l}^{-1}$ (Steinberg et al. 2001, Lomas et al. 2013), rarely would approach the level required to negatively impact salp feeding.

In contrast to other salp species, $W$. cylindrica abundance was positively correlated with both SST and water column stratification, while it was not significantly correlated with chl $a$, and was most abundant during the late summer (July, August, and September). This difference in seasonal abundance may be due to $W$. cylindrica's apparent preference for warm tropical waters. $W$. cylindrica is not reported in waters colder than $17^{\circ} \mathrm{C}$ (van Soest 1975), and Harbison \& Campenot (1979) experimentally determined that $W$. cylindrica stopped swimming at temperatures colder than $\sim 5^{\circ} \mathrm{C}$. However, Harbison \& Campenot (1979) also reported that C. polae demonstrated a response to cold temperatures similar to that of $W$. cylindrica. This is in contrast to our results, which indicate higher C. polae abundance in cool, high-phytoplankton-biomass conditions, suggesting that food availability has more influence than temperature on C. polae abundance.

\section{Diel vertical migration}

Five species (S. fusiformis, I. zonaria, S. aspera, Ritteriela retracta, and W. cylindrica) exhibited clear DVM, with significantly higher night vs. day biomass in the top $150 \mathrm{~m}$. Madin et al. (1996) also found DVM off Bermuda in S. fusiformis, I. zonaria, S. aspera, and $R$. retracta, but additionally in Ihlea punctata. In the slope waters of the NE USA, $S$. aspera also exhibited DVM (Madin et al. 2006). The most abundant vertically migrating species, $S$. fusiformis, was also negatively correlated with mesopelagic zone temperature (300-600 m), suggesting that warming of waters at typical daytime residence depths for vertical migrators in the region (e.g. Steinberg et al. 2000, 2012, Bianchi et al. 2013) could have a negative impact on $S$. fusiformis populations, such as increasing their metabolism at depth. While the most abundant species, $T$. democratica, did not exhibit DVM during times of average or low abundance, there was an 


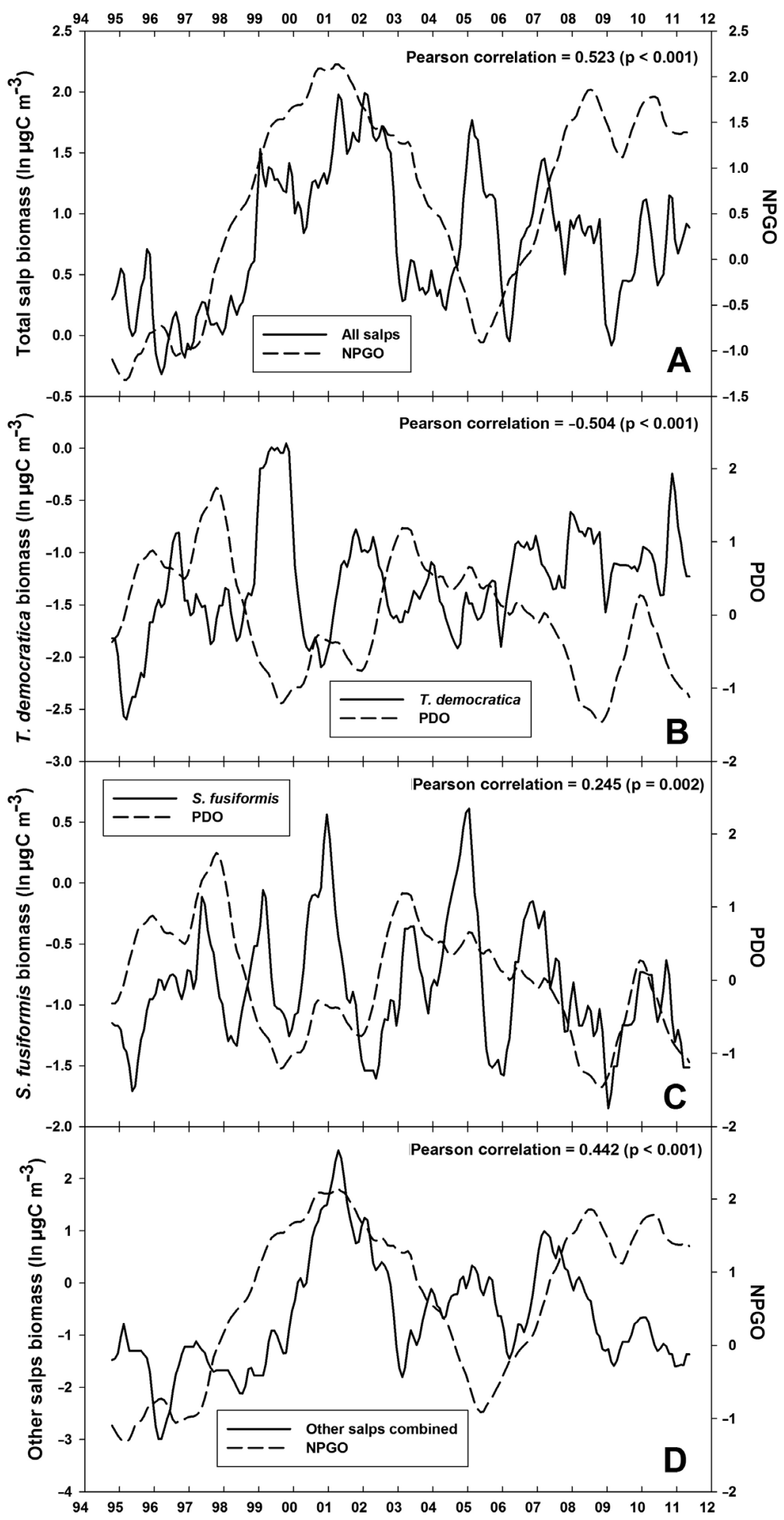

Fig. 10. Salp biomass and climate index 12 mo moving average. Monthly salp biomass trend (solid line) is shown with the most strongly correlated monthly climate index trend (dashed line). (A) Total salps with North Pacific Gyre Oscillation (NPGO), (B) Thalia democratica and (C) Salpa fusiformis with Pacific Decadal Oscillation (PDO), and (D) total salps minus T. democratica, S. fusiformis, Weelia (Salpa) cylindrica, and Cyclosalpa polae with the NPGO. Correlations between salp trends and climate indices were tested using the Pearson correlation (see Table 3 for full results of analysis) for the period of the salp time series (October 1994-May 2011)

dances could amplify the patchiness of the bloom. This is supported by both 'normal' and reverse $T$. democratica DVM on different sampling days during individual blooms in both 1996 and 2011. Other studies in the Agulhas Bank (Gibbons 1997), off SW Taiwan (Tew \& Lo 2005), and in the Kuroshio Current (Tsuda \& Nemoto 1992) found that T. democratica did not exhibit DVM and generally stayed within the upper $200 \mathrm{~m}$. Thus, we conclude that the diel differences we detected in $T$. democratica were likely due to bloom patchiness and that $T$. democratica likely does not undergo significant DVM.

\section{Mesoscale eddies}

Mesoscale eddies can enhance nutrient upwelling and PP in the BATS region (McGillicuddy et al. 2007, Mouriño-Carballido 2009) as well as the oligotrophic North Pacific gyre (Landry et al. 2008). Eddy presence can also lead to increases in biomass and changes in the community composition of mesozooplankton (Goldthwait \& Steinberg 2008, Eden et al. 2009). The only salp species that significantly changed in biomass in response to mesoscale eddies was $T$. democratica, which had elevated biomass in cyclonic eddies compared to the absence of eddies or anticyclonic eddies (Fig. 5). The first eddy data set we used (Chelton et al. 2011) does not distinguish between the 2 anticyclonic eddy types: anticyclonic eddies that are downwelling, and anticyclonic mode-water eddies with isopycnal displacement and upwelling. However, when using the Mouriño-Carballido (2009) data, which do distinguish these eddy types, we found no significant difference between $T$. democratica median biomass indication of DVM (both 'normal' and reverse) during different large T. democratica blooms. However, this is likely an artifact of horizontal movement of the salps rather than vertical, as extremely high abun- 
between anticylonic mode-water and anticyclonic eddies, although the low number of anticyclonic eddies (4) may be an insufficient sample size with which to detect a significant difference.

Increases in $T$. democratica biomass in response to cyclonic mesoscale eddies may be the result of several processes. Everett et al. (2011) reported T. democratica blooming within a $30 \mathrm{~km}$ cold-core, cyclonic eddy off southeast Australia, with an estimated abundance of over 5000 ind. $\mathrm{m}^{-3}$. This high abundance of salps in the cyclonic eddy was linked to an uplift of the nutricline and elevated fluorescence (Everett et al. 2011). While an increase in salps and other zooplankton in cyclonic eddies compared with the absence of eddy perturbation might be predicted, it is less clear why $T$. democratica was the only salp species to significantly increase in biomass in eddies. It is possible that only this most abundant species occurs in numbers large enough to detect differences between eddy types and that other salps may be responding to eddy perturbation as well. Alternatively, differences in phytoplankton community structure between eddy types may play a role. Previous studies showed that in anticyclonic mode-water eddies in the BATS region there was an increase in the percentage of larger phytoplankton such as diatoms and dinoflagellates $(2-200 \mu \mathrm{m})$, while in cyclonic eddies there was an increased percentage of cyanobacteria such as Synechococcus and Prochloro-

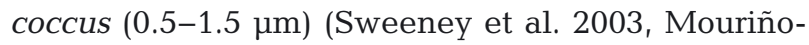
Carballido 2009). If $T$. democratica can outcompete other salp species in cyanobacteria-dominated phytoplankton assemblages, this shift in phytoplankton may explain why only $T$. democratica increased in the presence of cyclonic eddies. Although early studies showed that smaller salps could feed more efficiently on smaller particles (Harbison \& McAlister 1979, Kremer \& Madin 1992) and that T. democratica can feed on bacteria (Mullin 1983), a recent study shows that at least one large salp (Pegea confoederata) can also feed on sub-micrometer particles (Sutherland et al. 2010b).

\section{Long-term trends}

The only significant long-term trends in salp abundance or biomass at BATS were slight increases in $T$. democratica and C. polae biomass. While the trend in $T$. democratica was consistent over the time series, the trend in $C$. polae was mostly driven by the extremely low concentrations during the first $2 \mathrm{yr}$ of the study. For $T$. democratica, the increase was equivalent to an integrated $(0-150 \mathrm{~m})$ biomass increase of $1.43 \mu \mathrm{g} \mathrm{C} \mathrm{m}^{-2} \mathrm{yr}^{-1}$ or $\sim 10.0 \mu \mathrm{g}$ dry weight $\mathrm{m}^{-2} \mathrm{yr}^{-1}$ (assuming $\mathrm{C}=12.8 \%$ dry weight; Madin et al. 1981), and represents an increase of $\sim 0.17 \mathrm{mg}$ dry weight $\mathrm{m}^{-2}(85 \%)$ over the $17 \mathrm{yr}$ time series. While this increase is small compared to an increase of $10.7 \mathrm{mg}$ dry weight $\mathrm{m}^{-2}$ in total mesozooplankton biomass at BATS over the same time period (Steinberg et al. 2012), any shift in the baseline of salp biomass will have larger impacts seasonally at bloom concentrations. Significant long-term changes in salp abundance have been documented in other regions, including a long-term decrease in the California Current (Lavaniegos \& Ohman 2007) and a range expansion in the Southern Ocean (Atkinson et al. 2004). In other regions, salp abundance was positively associated with changes in primary production (Baird et al. 2011, Li et al. 2011).

There has been a $2 \%$ increase per year in net PP from 1989 to 2007 at BATS (Saba et al. 2010). This may be driving the long-term increase in $T$. democratica, as suggested by the significant positive correlation with long-term trends in primary production and their close grouping in the PCA of long-term trends. Chl a was not as good a predictor of salp biomass; while PP and chl a are significantly positively correlated at BATS over the long term $(p<0.001)$, salps at bloom abundances may quickly deplete chl a concentrations. Interestingly, long-term trends in both $T$. democratica and C. polae are positively correlated with the WCSI, which has also been increasing over the time series. While an increase in the WCSI would reduce the amount of mixing and nutrient influx into surface waters, this overall increase may not be affecting winter-time advective mixing, which is most important for driving the BATS spring phytoplankton bloom (Lomas et al. 2010, Lomas et al. 2013).

In addition to a long-term increase, there were unusually large spring blooms of $T$. democratica every third year starting in 1996, as well as elevated biomass of this species throughout the remainder of those years. No other salp species showed a similar cycle of blooms or abundance. Globally, salps have been shown to follow approximately a 4 yr cycle of high and low relative abundance (Condon et al. 2013, their supplementary Fig. S2c). Condon et al. (2013) posit that this may be related to the $4.4 \mathrm{yr}$ quasi-cycle of high tidal levels based on the lunar perigee (the closest distance the moon is to Earth; Haigh et al. 2011), during which an increase in internal tidal wave energy causes an increase in turbulence and mixing over the deep ocean (Garrett 2003). However, we have no mechanistic evidence of a link 
between this $4.4 \mathrm{yr}$ cycle of increased mixing and the slightly offset $3 \mathrm{yr}$ cycle of $T$. democratica we detected, and no other explanation for the pattern.

\section{Climate oscillations}

Decadal climate oscillations play an important role in regulating long-term trends in physical forcing and biological response in the North Atlantic (Greene et al. 2003) and specifically in the BATS region (Krause et al. 2009, Lomas et al. 2010, Saba et al. 2010, Steinberg et al. 2012). The phase of the NAO influences the ecology of the North Atlantic through changes in temperature, circulation patterns, and wind intensity (Ottersen et al. 2001). In the BATS region, a negative phase in the NAO results in increased storm activity (Dickson et al. 1996), which causes an increase in the frequency of mixing in the region (Lomas et al. 2010). This increased mixing leads to an increase in primary production (Saba et al. 2010), higher chl a (Lomas et al. 2010), and increased mesozooplankton biomass (Steinberg et al. 2012). In our analysis, a negative NAO correlated with an increase in chl $a$ and biomass and abundance of C. polae, but not with an increase in biomass of the 3 most abundant species of salps.

Due to climate teleconnections between the North Atlantic and other ocean basins (Kucharski et al. 2006, Müller et al. 2008), PP and mesozooplankton biomass are also positively correlated with the NPGO (Saba et al. 2010, Steinberg et al. 2012). The NPGO was positively correlated with long-term trends in total salp biomass and abundance. The other Pacific climate indices, MEI and PDO, both decreased while total salp biomass, abundance, and the NPGO increased. This suggests that salp biomass is influenced through a similar mechanism by the 3 Pacific indices while the NAO has little or no effect on longterm trends in salp biomass. Thalia democratica was also significantly correlated with the Pacific oscillation indices but not with the NAO, again suggesting that variability in these climate indices affects physical forcing, ultimately leading to salp blooms in the BATS region in different ways. The PDO was negligibly correlated with long-term trends in S. fusiformis, and no climate index was correlated with $W$. cylindrica biomass. It is likely that the processes affecting their long-term trends are unrelated to the mechanism linking the Pacific indices and T. democratica. El Niño Southern Oscillation (ENSO) forcing affects Southern Ocean salp populations (S. thompsoni), but the nature of the environmental conditions driven by this forcing, which leads to years with large summer blooms of $S$. thompsoni, is still unknown (Loeb \& Santora 2012). Similarly, the mechanism by which forcing associated with these Pacific climate oscillations affect changes in BATS region ecology remains to be determined.

\section{CONCLUSIONS}

The high diversity and seasonal increase in abundance of salps in the BATS region has important implications for trophic interactions in the planktonic food web, as during blooms salps periodically make up more than $90 \%$ of the mesozooplankton biomass. Grazing by salp blooms and competition with other mesozooplankton could alter the phytoplankton and zooplankton community structure in ways that persist after the salp blooms have died off by changing the relative ratios of different phytoplankton groups. These high abundances, coupled with the high filtration rates of salps, could also efficiently transfer carbon to the deep pelagic ocean and benthos, through rapid sinking of their large fecal pellets, sinking of salp carcasses, and active transport by DVM. In conjunction with a long-term increase in PP at BATS, there has been a corresponding long-term increase in T. democratica and C. polae biomass, and longterm trends in other species may emerge as the data set continues. Salp populations are clearly sensitive to both seasonal and multi-year changes in environmental conditions, and each species responds uniquely to environmental changes. While the links between climate oscillations and changes in salp populations need to be further explored, increased warming of the oceans and resultant changes in decadal climate oscillations could lead to future changes in salp abundance.

Acknowledgements. We are grateful to the many Bermuda Atlantic Time-series Study (BATS) technicians and personnel involved in the sampling and maintenance of the zooplankton time series over the last 2 decades. We appreciate the support of the officers and crew of the R/V 'Weatherbird II' and the R/V 'Atlantic Explorer' for help with sample collection. Special thanks goes to Joseph Cope for assistance with data management and analysis and to Rob Condon for helpful discussions about our results. The BATS zooplankton time series was initially funded by National Science Foundation (NSF) grant OCE-9202336 to L. P. Madin, and continued by the BATS program through the NSF Chemical and Biological Oceanography programs (OCE-9301950, OCE9617795, and OCE-0326885), and through OCE-0752366 and OCE-1258622 to D.K.S., which funded this current effort. This paper is Contribution No. 3396 of the Virginia Institute of Marine Science, College of William \& Mary. 


\section{LITERATURE CITED}

Álvarez-García FJ, Ortiz-Bevia MJ, Cabos-Narvaez WD (2011) On the structure and teleconnections of North Atlantic decadal variability. J Clim 24:2209-2223

Andersen V (1998) Salp and pyrosomid blooms and their importance in biogeochemical cycles. In: Bone $Q$ (ed) The biology of pelagic tunicates. Oxford University Press, New York, NY, p 125-137

> Atkinson A, Siegel V, Pakhomov E, Rothery P (2004) Longterm decline in krill stock and increase in salps within the Southern Ocean. Nature 432:100-103

Baird ME, Everett JD, Suthers IM (2011) Analysis of southeast Australian zooplankton observations of 1938-42 using synoptic oceanographic conditions. Deep-Sea Res II 58:699-711

Bathmann UV (1988) Mass occurrence of Salpa fusiformis, in the spring of 1984 off Ireland: implications of sedimentation processes. Mar Biol 97:127-135

> Bianchi D, Galbraith ED, Carozza DA, Mislan KAS, Stock CA (2013) Intensification of open-ocean oxygen depletion by vertically migrating animals. Nat Geosci 6: $545-548$

Bone Q, Carre C, Chang P (2003) Tunicate feeding filters. J Mar Biol Assoc UK 83:907-919

> Caron DA, Madin LP, Cole JJ (1989) Composition and degradation of salp fecal pellets: implications for vertical flux in oceanic environments. J Mar Res 47:829-850

Chelton DB, Schlax MG, Samelson RM (2011) Global observations of nonlinear mesoscale eddies. Prog Oceanogr 91:167-216

Condon RH, Duarte CM, Pitt KA, Robinson KL and others (2013) Recurrent jellyfish blooms are a consequence of global oscillations. Proc Natl Acad Sci USA 110:1000-1005

Conte MH, Ralph N, Ross EH (2001) Seasonal and interannual variability in deep ocean particle fluxes at the Oceanic Flux Program (OFP)/Bermuda Atlantic Time Series (BATS) site in the western Sargasso Sea near Bermuda. Deep-Sea Res II 48:1471-1505

> Daponte MC, Calcagno JA, Acevedo-Luque MJJ, Martos P, Machinandiarena L, Esnal GB (2011) Composition, density, and biomass of Salpidae and Chaetognatha in the southwestern Atlantic Ocean $\left(34.5^{\circ} \mathrm{S}-39^{\circ} \mathrm{S}\right)$. Bull Mar Sci 87:437-461

> Deibel D, Paffenhöfer GA (2009) Predictability of patches of neritic salps and doliolids (Tunicata, Thaliacea). J Plankton Res 31:1571-1579

> Dickson R, Lazier J, Meincke J, Rhines P, Swift J (1996) Long-term coordinated changes in the convective activity of the North Atlantic. Prog Oceanogr 38:241-295

- Eden BR, Steinberg DK, Goldthwait SA, McGillicuddy DJ (2009) Zooplankton community structure in a cyclonic and mode-water eddy in the Sargasso Sea. Deep-Sea Res I 56:1757-1776

> Everett JD, Baird ME, Suthers IM (2011) Three-dimensional structure of a swarm of the salp Thalia democratica within a cold-core eddy off southeast Australia. J Geophys Res 116:C12046, doi:10.1029/2011JC007310

- Fernex FE, Braconnot JC, Dallot S, Boisson M (1996) Is ammonification rate in marine sediment related to plankton composition and abundance? A time-series study in Villefranche Bay (NW Mediterranean). Estuar Coast Shelf Sci 43:359-371

Garrett C (2003) Internal tides and ocean mixing. Science 301:1858-1859
Gibbons MJ (1997) Vertical distribution and feeding of Thalia democratica, on the Agulhas Bank during March 1994. J Mar Biol Assoc UK 77:493-505

Godeaux J, Bone Q, Braconnot JC (1998) Anatomy of Thaliacea. In: Bone Q (ed) The biology of pelagic tunicates. Oxford University Press, New York, NY, p 1-24

Goldthwait SA, Steinberg DK (2008) Elevated biomass of mesozooplankton and enhanced fecal pellet flux in cyclonic and mode-water eddies in the Sargasso Sea. Deep-Sea Res II 55:1360-1377

González HE, Sobarzo M, Figueroa D, Nöthig EM (2000) Composition, biomass and potential grazing impact of the crustacean and pelagic tunicates in the northern Humboldt Current area off Chile: differences between El Niño and non-El Niño years. Mar Ecol Prog Ser 195: 201-220

> Greene $\mathrm{CH}$, Pershing AJ, Conversi A, Planque B and others (2003) Trans-Atlantic responses of Calanus finmarchicus populations to basin-scale forcing associated with the North Atlantic Oscillation. Prog Oceanogr 58:301-312

Haigh ID, Eliot M, Pattiaratchi C (2011) Global influences of the 18.61 year nodal cycle and 8.85 year cycle of lunar perigee on high tidal levels. J Geophys Res 116:C06025, doi:10.1029/2010JC006645

> Harbison GR, Campenot RB (1979) Effects of temperature on the swimming of salps (Tunicata, Thaliacea): implications for vertical migration. Limnol Oceanogr 24:1081-1091

> Harbison GR, McAlister VL (1979) The filter-feeding rates and particle retention efficiencies of three species of Cyclosalpa (Tunicata, Thaliacea). Limnol Oceanogr 24: 875-892

Harbison GR, McAlister VL, Gilmer RW (1986) The response of the salp, Pegea confoederata, to high levels of particulate material: starvation in the midst of plenty. Limnol Oceanogr 31:371-382

- Henschke N, Everett JD, Baird ME, Taylor MD, Suthers IM (2011) Distribution of life-history stages of the salp Thalia democratica in shelf waters during a spring bloom. Mar Ecol Prog Ser 430:49-62

> Henschke N, Bowden DA, Everett JD, Holmes SP, Kloser RJ, Lee RW, Suthers IM (2013) Salp-falls in the Tasman Sea: a major food input to deep-sea benthos. Mar Ecol Prog Ser 491:165-175

Hereu CM, Lavaniegos BE, Gaxiola-Castro G, Ohman MD (2006) Composition and potential grazing impact of salp assemblages off Baja California during the 1997-1999 El Niño and La Niña. Mar Ecol Prog Ser 318:123-140

> Heron AC (1972) Population ecology of a colonizing species: the pelagic tunicate Thalia democratica. I. Individual growth rate and generation time. Oecologia 10:269-293

Heron AC, McWilliam PS, Dal Pont G (1988) Length-weight relation in the salp Thalia democratica and potential of salps as a source of food. Mar Ecol Prog Ser 42:125-132

Huskin I, Elices MA, Anadón R (2003) Salp distribution and grazing in a saline intrusion off NW Spain. J Mar Syst 42: $1-11$

Knap AH, Michaels AF, Steinberg DK, Bahr F and others (1997) BATS methods manual. US JGOFS Planning Office, Woods Hole, MA

> Krause JW, Nelson DM, Lomas MW (2009) Biogeochemical responses to late-winter storms in the Sargasso Sea, II: Increased rates of biogenic silica production and export. Deep-Sea Res I 56:861-874

Kremer P, Madin LP (1992) Particle retention efficiency of salps. J Plankton Res 14:1009-1015 
Kucharski F, Molteni F, Bracco A (2006) Decadal interactions between the western tropical Pacific and the North Atlantic Oscillation. Clim Dyn 26:79-91

Landry MR, Brown SL, Rii YM, Selph KE, Bidigare RR, Yang EJ, Simmons MP (2008) Depth-stratified phytoplankton dynamics in Cyclone Opal, a subtropical mesoscale eddy. Deep-Sea Res II 55:1348-1359

> Lavaniegos BE, Ohman MD (2007) Coherence of long-term variations of zooplankton in two sectors of the California Current System. Prog Oceanogr 75:42-69

Lebrato M, Jones DOB (2009) Mass deposition event of Pyrosoma atlanticum carcasses off Ivory Coast (West Africa). Limnol Oceanogr 54:1197-1209

Lebrato M, Mendes PJ, Steinberg DK, Cartes JE and others (2013) Jelly biomass sinking speed reveals a fast carbon export mechanism. Limnol Oceanogr 58:1113-1122

Li K, Yin J, Huang L, Shang J, Lian S, Liu C (2011) Distribution and abundance of thaliaceans in the northwest continental shelf of South China Sea, with response to environmental factors driven by monsoon. Cont Shelf Res 31: 979-989

> Licandro P, Ibañez F, Etienne M (2006) Long-term fluctuations (1974-1999) of the salps Thalia democratica and Salpa fusiformis in the Northwestern Mediterranean Sea: relationships with hydroclimatic variability. Limnol Oceanogr 51:1832-1848

> Liu Y, Sun S, Zhang G (2012) Seasonal variation in abundance, diel vertical migration and body size of pelagic tunicate Salpa fusiformis in the Southern Yellow Sea. Chin J Oceanology Limnol 30:92-104

> Loeb VJ, Santora JA (2012) Population dynamics of Salpa thompsoni near the Antarctic Peninsula: growth rates and interannual variations in reproductive activity (1993-2009). Prog Oceanogr 96:93-107

Loeb VJ, Hofmann EE, Klinck JM, Osmund HH (2010) Hydrographic control of the marine ecosystem in the South Shetland-Elephant Island and Bransfield Strait region. Deep-Sea Res II 57:519-542

> Lomas MW, Steinberg DK, Dickey T, Carlson CA, Nelson NB, Condon RH, Bates NR (2010) Increased ocean carbon export in the Sargasso Sea linked to climate variability is countered by its enhanced mesopelagic attenuation. Biogeosciences 7:57-70

Lomas MW, Bates NR, Johnson RJ, Knap AH, Steinberg DK, Carlson CA (2013) Two decades and counting: 24-years of sustained open ocean biogeochemical measurements in the Sargasso Sea. Deep-Sea Res II 93:16-32

Madhupratap M, Devassy VP, Sreekumaran-Nair SR, Rao TSS (1980) Swarming of pelagic tunicates associated with phytoplankton bloom in the Bay of Bengal. Indian J Mar Sci 9:69-71

> Madin LP (1982) Production, composition and sedimentation of salp pellets in oceanic waters. Mar Biol 67:39-45

Madin LP, Deibel D (1998) Feeding and energetics of Thaliacea. In: Bone Q (ed) The biology of pelagic tunicates. Oxford University Press, Oxford, p 81-103

> Madin LP, Kremer P (1995) Determination of the filter feeding rates of salps (Tunicata, Thaliacea). ICES J Mar Sci 52:583-595

> Madin LP, Purcell JE (1992) Feeding, metabolism, and growth of Cyclosalpa bakeri in the subarctic Pacific. Limnol Oceanogr 37:1236-1251

Madin LP, Cetta CM, McAlister VL (1981) Elemental and biochemical composition of salps (Tunicata: Thaliacea). Mar Biol 63:217-226
Madin LP, Kremer P, Hacker S (1996) Distribution and vertical migration of salps (Tunicata, Thaliacea) near Bermuda. J Plankton Res 18:747-755

Madin LP, Horgan EF, Steinberg DK (2001) Zooplankton at the Bermuda Atlantic Time-series Study (BATS) station: diel, seasonal and interannual variation in biomass, 1994-1998. Deep-Sea Res II 48:2063-2082

Madin LP, Kremer P, Wiebe PH, Purcell JE, Horgan EH, Nemazie DA (2006) Periodic swarms of the salp Salpa aspera in the Slope Water off the NE United States: biovolume, vertical migration, grazing and vertical flux. Deep-Sea Res I 53:804-819

> McGillicuddy DJ, Robinson AR, Siegel DA, Jannasch HW and others (1998) Influence of mesoscale eddies on new production in the Sargasso Sea. Nature 394:263-266

McGillicuddy DJ, Anderson LA, Bates NR, Bibby T and others (2007) Eddy/wind interactions stimulate extraordinary mid-ocean plankton blooms. Science 316: 1021-1026

Ménard F, Dallot S, Thomas G, Braconnot JC (1994) Temporal fluctuations of two Mediterranean salp populations from 1967 to 1990. Analysis of the influence of environmental variables using a Markov chain model. Mar Ecol Prog Ser 104:139-152

> Mouriño-Carballido B (2009) Eddy-driven pulses of respiration in the Sargasso Sea. Deep-Sea Res I 56:1242-1250

Müller WA, Frankignoul C, Chouaib N (2008) Observed decadal tropical Pacific-North Atlantic teleconnections. Geophys Res Lett 35:L24810, doi:10.1029/2008GL035901

> Mullin MM (1983) In situ measurement of filtering rates of the salp, Thalia democratica, on phytoplankton and bacteria. J Plankton Res 5:279-288

Nishikawa J, Terazaki M (1996) Tissue shrinkage of two gelatinous zooplankton, Thalia democratica and Dolioletta gegenbauri (Tunicata: Thaliacea) in preservative. Bull Plankton Soc Japan 43:1-7

> Ottersen G, Planque B, Belgrano A, Post E, Reid PC, Stenseth NC (2001) Ecological effects of the North Atlantic Oscillation. Oecologia 128:1-14

> Paffenhöfer GA, Lee TN (1987) Development and persistence of patches of Thaliacea. S Afr J Mar Sci 5:305-318

Phillips B, Kremer P, Madin LP (2009) Defecation by Salpa thompsoni and its contribution to vertical flux in the Southern Ocean. Mar Biol 156:455-467

> Pyper BJ, Peterman RM (1998) Comparison of methods to account for autocorrelation in correlation analyses of fish data. Can J Fish Aquat Sci 55:2127-2140

Roman MR, Adolf HA, Landry MR, Madin LP, Steinberg DK, Zhang X (2002) Estimates of oceanic mesozooplankton production: a comparison using the Bermuda and Hawaii time-series data. Deep-Sea Res II 49:175-192

Saba VS, Friedrichs MAM, Carr M-E, Antoine D and others (2010) Challenges of modeling depth-integrated marine primary productivity over multiple decades: a case study at BATS and HOT. Global Biogeochem Cycles 24: GB3020, doi:10.1029/2009GB003655

Stammerjohn S, Massom R, Rind D, Martinson D (2012) Regions of rapid sea ice change: an inter-hemispheric seasonal comparison. Geophys Res Lett 39:L06501, doi: 10.1029/2012GL050874

> Steinberg DK, Carlson CA, Bates NR, Goldthwait SA, Madin LP, Michaels AF (2000) Zooplankton vertical migration and the active transport of dissolved organic and inorganic carbon in the Sargasso Sea. Deep-Sea Res I 47: 137-158 
Steinberg DK, Carlson CA, Bates NR, Johnson RJ, Michaels AF, Knap AH (2001) Overview of the US JGOFS Bermuda Atlantic Time-series Study (BATS): a decade-scale look at ocean biology and biogeochemistry. Deep-Sea Res II 48:1405-1447

Steinberg DK, Lomas MW, Cope JS (2012) Long-term increase in mesozooplankton biomass in the Sargasso Sea: linkage to climate and implications for food web dynamics and biogeochemical cycling. Global Biogeochem Cycles 26:GB1004, doi:10.1029/2010GB004026

Sutherland KR, Beet AR, Solow AR (2010a) Re-analysis of a salp population time-series. Mar Ecol Prog Ser 418: $147-150$

Sutherland KR, Madin LP, Stocker R (2010b) Filtration of submicrometer particles by pelagic tunicates. Proc Natl Acad Sci USA 107:15129-15134

Sweeney EN, McGillicuddy DJ, Buesseler KO (2003) Biogeochemical impacts due to mesoscale eddy activity in the Sargasso Sea as measured at the Bermuda Atlantic Time-series Study (BATS). Deep-Sea Res II 50:3017-3039

Tew KS, Lo T (2005) Distribution of Thaliacea in SW Taiwan coastal water in 1997, with special reference to Doliolum denticulatum, Thalia democratica, and T. orientalis. Mar Ecol Prog Ser 292:181-193

Tsuda A, Nemoto T (1992) Distribution and growth of salps in a Kuroshio warm-core ring during summer 1987.

Submitted: November 25, 2013; Accepted: August 4, 2014
Deep-Sea Res 39(S1):S219-S229

van Soest RWM (1975) Thaliacea of the Bermuda area. Bull Zool Mus Univ Amsterdam 5:7-12

van Soest RWM (1998) The cladistics biogeography of salps and pyrosomas. In Bone Q (ed) The biology of pelagic tunicates. Oxford University Press, New York, NY, p 231-249

Vaughan DG, Marshall GJ, Connolley WM, Parkinson C and others (2003) Recent raid regional climate warming on the Antarctic Peninsula. Clim Change 60:243-274

Wu S, Liu Z, Zhang R, Delworth TL (2011) On the observed relationship between the Pacific Decadal Oscillation and the Atlantic Multi-decadal Oscillation. J Oceanogr 67: 27-35

Yoon WD, Marty JC, Sylvain D, Nival P (1996) Degradation of fecal pellets in Pegea confoederata (Salpidae, Thaliacea) and its implication in the vertical flux of organic matter. J Exp Mar Biol Ecol 203:147-177

Yoon WD, Kim SK, Han KN (2001) Morphology and sinking velocities of fecal pellets of copepod, molluscan, euphausiid, and salp taxa in the northeastern tropical Atlantic. Mar Biol 139:923-928

> Zeldis JR, Davis CS, James MR, Ballara SL, Booth WE, Chang FH (1995) Salp grazing: effects on phytoplankton abundance, vertical distribution and taxonomic composition in a coastal habitat. Mar Ecol Prog Ser 126:267-283

Proofs received from author(s): September 3, 2014 